\title{
Article \\ In Silico Predictions of Ecological Plasticity Mediated by Protein Family Expansions in Early-Diverging Fungi
}

\author{
Małgorzata Orłowska * ${ }^{(D)}$ and Anna Muszewska *D
}

Citation: Orłowska, M.; Muszewska, A. In Silico Predictions of Ecological Plasticity Mediated by Protein Family Expansions in Early-Diverging Fungi. J. Fungi 2022, 8, 67. https://doi.org/ $10.3390 /$ jof 8010067

Academic Editors: Dietmar Schlosser, Paul Olusegun Bankole and Cheng Gao

Received: 9 November 2021

Accepted: 7 January 2022

Published: 9 January 2022

Publisher's Note: MDPI stays neutral with regard to jurisdictional claims in published maps and institutional affiliations.

Copyright: (C) 2022 by the authors. Licensee MDPI, Basel, Switzerland. This article is an open access article distributed under the terms and conditions of the Creative Commons Attribution (CC BY) license (https:// creativecommons.org/licenses/by/ $4.0 /$ )
Institute of Biochemistry and Biophysics, Polish Academy of Sciences, Pawinskiego 5A, 02-106 Warsaw, Poland

* Correspondence: orlowskamga@gmail.com (M.O.); musze@ibb.waw.pl (A.M.)

\begin{abstract}
Early-diverging fungi (EDF) are ubiquitous and versatile. Their diversity is reflected in their genome sizes and complexity. For instance, multiple protein families have been reported to expand or disappear either in particular genomes or even whole lineages. The most commonly mentioned are CAZymes (carbohydrate-active enzymes), peptidases and transporters that serve multiple biological roles connected to, e.g., metabolism and nutrients intake. In order to study the link between ecology and its genomic underpinnings in a more comprehensive manner, we carried out a systematic in silico survey of protein family expansions and losses among EDF with diverse lifestyles. We found that 86 protein families are represented differently according to EDF ecological features (assessed by median count differences). Among these there are 19 families of proteases, 43 CAZymes and 24 transporters. Some of these protein families have been recognized before as serine and metallopeptidases, cellulases and other nutrition-related enzymes. Other clearly pronounced differences refer to cell wall remodelling and glycosylation. We hypothesize that these protein families altogether define the preliminary fungal adaptasome. However, our findings need experimental validation. Many of the protein families have never been characterized in fungi and are discussed in the light of fungal ecology for the first time.
\end{abstract}

Keywords: protein family; peptidases; cazymes; earl diverging fungi; cell wall; adaptasome

\section{Introduction}

The Fungi are a large Kingdom of eukaryotic organisms. They vary in chemical composition, morphological forms, genomic architectures, and ecology. Fungal life strategies range from organic-matter-decomposing saprotrophs to obligate mutualists and harmful pathogens [1]. As fungi are sessile osmotrophic organisms, they owe their lifestyle diversity to the repertoire of secreted proteins (secretome) that play a major role in nutrient degradation and assimilation. The secretome also takes part in protection from the host's immune system [2] or in moderating relations with mycorrhizal partners [3]. Fungal secretome composition is reflected in their genomes.

Basically, the Kingdom Fungi is divided into two main groups. The first group is the subkingdom Dikarya, which comprises the evolutionarily young phyla: Ascomycota, Basidiomycota, and Entorrhizomycota. The second group, called early-diverging fungi (EDF) or basal fungi, is composed of the phyla: Blastocladiomycota, Monoblepharidomycota, Neocallimastigomycota, Chytridiomycota, Mucoromycota, Zoopagomycota, and the group Opisthosporidia [1]. The majority of mycological studies are focused on Dikarya, while research on EDF is rather limited. Due to these trends, the ecological importance and modes of life of basal fungi remain largely unknown [4]. Early-diverging fungi live in a variety of ecological niches. They also occur in the aquatic environment as on land. Terrestrialization brought new challenges to early-diverging lineages and promoted the eventual formation of hyphae. It is a matter of debate regarding which particular group was the first to develop the true hyphae, but it was one of the three labelled as BCZ (Blastocladiomycota, Chytridiomycota, Zoopagomycota) nodes in the seminal work by Kiss and coworkers [5]. EDF adapted to 
life on land are often preferentially associated with plants and soil (e.g., Mucoromycota) or animals (Zoopagomycota), while those living in water or having an intermediate lifestyle are versatile saprotrophs living on pollen, algal and animal parasites (Blastocladiomycota, Chytridiomycota) [6].

Evolutionary forces shape gene families by means of duplications and losses, leading to complex patterns of gene family distribution on the tree of life [7]. Fungal genomes are no exception here, with a plethora of documented duplications, including whole-genome duplications and massive gene losses [8,9]. The expansion or retrogression of gene families has been described as a general mechanism for adaptation to occupy different niches [10]. We hypothesize that for fungi this statement is especially true when it comes to genes encoding proteins belonging to particular families. Some nodes of the Fungal Tree of Life (FTol) are particularly abundant in losses as an exemplification of selective pressure acting on parasitic (e.g., Candida, Magnaporthe, Metarhizium, Pneumocystis), symbiotic (e.g., Glomus), or yeast-like organisms (e.g., Saccharomycotina, Malassezia, Rhodotorula) [11]. On the other hand, gene proliferation with gene families related to a particular ecological niche has been documented in plant-degrading saprotrophs and pathogens (white rot and brown rot fungi-laccases, peroxidases, cellulases) [12], entomopathogens (Metarhizium, lipases and proteases) [13], and skin-associated fungi (Malassezia lipases and proteases) [14]. Moreover, most fungal genome papers describe expanded and contracted protein families with a limited number of protein domains, referred to repeatedly in diverse contexts ranging from pathogenicity (e.g., proteases) to stress tolerance (e.g., SODs-superoxide dismutases). Usually, these protein families (especially proteases and CAZymes) are described in the context of an ecological niche. However, many of these proteins contribute to a range of ecological adaptations often beyond a single primary lifestyle. These dispersed but recurring observations encouraged us to make a systematic study of changeable protein domains in EDF.

In this in silico study, we present 86 protein families putatively associated with the adaptation of early-diverging fungi to their lifestyle. Importantly, these include well known proteins and so far uncharacterized proteins. To achieve this, we mapped 45 EDF and 10 model Dikarya proteomes against three widely used protein domain databases: MEROPS [15], CAZy [16], and TCDB [17]. These databases collect information about proteases, carbohydrate-active enzymes (CAZymes), and membrane transport proteins. The main goal of this work is to systematize knowledge in the field of the fungal adaptasome with a special focus on understudied but ecologically vital EDF. Here, we provide a comprehensive list of protein families likely playing a role in fungal adaptation and at the same time a list of gene candidates for phenotyping.

\section{Materials and Methods}

\subsection{Data Acquisition, Proteome Mapping, and Protein Families Selection}

Forty-five predicted EDF and ten Dikarya proteomes were downloaded from NCBI in April 2018. Reference genome sequences are provided in Supplementary Table S4. In order to assess genome completeness, BUSCO with a fungal reference dataset fungi_odb10 was used; Rhizopus oryzae and Aspergillus nidulans were used as Augustus training species for EDF and Dikarya, respectively [18,19]. All proteomes were mapped against CAZY, MEROPS, and TCDB profile libraries. Sets of protein sequences were mapped against MEROPS and TCDB libraries with blastp [20] (e-value threshold of $1 \times 10^{-10}$ ). For annotation with CAZY profiles stored in dbCAN we used hmmscan [21]. The number of hits to each protein family were used to create tables describing the proteome content for all analysed fungi (Supplementary Table S1). Supplementary Table S2 contains information about the ecology of the analysed fungi derived from the literature (used labels are described below).

Studied organisms were divided into groups depending on the represented lifestyle. We used the following labels to describe these groups: pathogen, an opportunistic pathogen, saprotroph, commensal, mutualist, living in water, living on land, endophyte, associated 
with plants, and associated with animals. Each organism was assigned to all matching labels. Combining the Supplementary Tables S1 and S2, we obtained datasets containing labelled organisms, and counts of proteins belonging to CAZY, MEROPS, and TCDB protein families. In all of the ecological groups, a median of occurrences for each protein family was calculated. In the next step, groups were compared in pairs to check for median differences between the same protein families in fungi with divergent ecology. To verify that the difference in medians is statistically significant, the Mann-Whitney-Wilcoxon test was used. The test was selected due to the non-normal pattern of distribution (examined using the Shapiro-Wilk test). From every comparison, ten protein families with the greatest difference in median were listed. Protein families that occurred in three or more compared pairs were selected for further analysis.

\subsection{Sequence Alignment and Phylogenetic Analysis}

Sequences belonging to each picked protein family were aligned using the local iterative alignment method in Mafft v. 3.7 (localpair, maxiterate = 100) [22]. All alignments with homologs of MEROPS and CAZY proteins were curated manually. All proteins with deletions in the conserved regions of the enzymatic domain and/or with deletion or invalid substitution in any of the catalytic residues were excluded. As an invalid substitution, we recognized cases in which catalytic residue was replaced with an amino acid whose physical or chemical properties prevented it from performing the function expected for catalytic residue. The curation process was based on published experimental mutations in catalytic residues and/or the properties of given amino acids, and PDB references.

Due to the low specificity of TCDB profiles, alignments related to this database were not curated as described above. Because some proteins were assigned to more than one TCDB profile during mapping, we additionally performed clustering in CLANS [23] for combined sets of families that contained ambiguous homologs.

All alignments were trimmed with TrimAl (model = gappyout) to remove poorly conserved regions [24]. Next, the IQ-TREE 2 [25] was used to predict the best model for phylogenetic analysis $(\mathrm{m}=\mathrm{MFP})$, and to build phylogenetic trees based on the Maximum Likelihood (ML) method. ML trees were estimated with aLRT Chi2-based parametric branch supports $(\mathrm{alrt}=0)$ and starting tree search from a random tree $(t=\mathrm{RANDOM})$.

For all analysed protein families, we assessed domain architecture (pfam_scan.pl [26]), protein localization and the presence of signal peptides (WoLF PSORT [27], SignalP v 5.0 [28].

Phylogenetic trees were visualized and annotated with iToL [29].

\section{Results and Discussion}

We identified 86 protein families which are over and underrepresented in EDF depending on ecological features (referred hereafter as the adaptasome). The adaptasome encompasses 19 MEROPS families of peptidases and inhibitors, 43 CAZymes and 24 transporters (Table 1). Several of the selected protein families have well documented roles in fungal biology, for instance, as cell-wall-related enzymes, while others have never been studied in EDF fungi (e.g., endo-1,4-beta-mannosidase GH26), in fungi in general (e.g., LARGE homologs from GT49) or even in Eukaryotes (e.g., CE12 rhamnogalacturonan acetylesterase or unknown peptidase U69 [30]). Depending on the available evidence, we aimed to provide a comprehensive interpretation of the possible contribution of particular protein families to EDF ecological adaptability.

In our results (Figure 1) one of the Rhizopus representants may draw attention following its outstanding expansion of many families. This is due to an additional round of wholegenome duplication in this strain [31]. 
Table 1. Summary of protein families with statistically significant changes in copy number distribution among early-diverging fungi (EDF). Functional annotations were based on UniProt, protein domain role and literature searches.

\begin{tabular}{|c|c|c|}
\hline \multicolumn{3}{|c|}{ MEROPS } \\
\hline MEROPS ID & Predicted Name & Putative Role in Fungi \\
\hline A01 & endopeptidase & Nutrition, pathogenicity \\
\hline $\mathrm{A} 28$ & retropepsin & Unknown \\
\hline C110 & $\begin{array}{l}\text { peptide- } \mathrm{N}(4)-(N \text {-acetyl- } \beta \text {-glucosaminyl }) \\
\text { asparagine amidase }\end{array}$ & Protein degradation \\
\hline $\mathrm{C} 14$ & caspases & Controlled cell death \\
\hline C19 & ubiquitin-carboxyl-hydrolase & Nutrition \\
\hline C46 & hint domain containing & Putative mating response \\
\hline G05 & type II CAAX-prenyl-endopeptidase & Protein modification \\
\hline I04 & serpin & Peptidase inhibitor \\
\hline M13 & unknown peptidase & Nutrition \\
\hline \multirow{2}{*}{ M20 } & $N$-acyl-L-amino-acid-amidohydrolase & Nutrition \\
\hline & unknown peptidase & Unknown \\
\hline \multirow{3}{*}{ M24 } & MAP1 & \multirow{2}{*}{$\begin{array}{l}\text { Maturation of the nascent polypeptide } \\
\text { during translation }\end{array}$} \\
\hline & MAP2 & \\
\hline & Xaa-Pro aminopeptidase & Nutrition \\
\hline M28 & glutamate carboxypeptidase & Unknown \\
\hline M36 & fungalysin & Nutrition, pathogenicity \\
\hline \multirow{6}{*}{ M38 } & allantoinase & \multirow{5}{*}{ Uric acid degradation pathway, pathogenicity } \\
\hline & unknown peptidase & \\
\hline & dihydroorotase & \\
\hline & guanine deaminase & \\
\hline & urease & \\
\hline & $N$-acetylglucosamine-6-phosphate-deacetylase & Chitin degradation \\
\hline S01 & serine protease (extracellular) & Nutrition \\
\hline S08 & subtilisin & Nutrition \\
\hline S54 & rhomboid proteases & Mitochondrial endopeptidase \\
\hline U69 & polysaccharide lyases & Nutrition \\
\hline \multicolumn{3}{|c|}{ CAZY } \\
\hline CAZY ID & Predicted Name & Putative Role in Fungi \\
\hline AA3 & glucose-methanol-choline (GMC) oxidoreductases & Nutrition \\
\hline AA5 & galactose oxidase & Nutrition \\
\hline AA6 & 1,4-benzoquinone reductase & Nutrition, interaction with insects \\
\hline AA7 & $\begin{array}{l}\text { glucooligosaccharide-oxidase/chitooligosaccharide- } \\
\text { oxidase/cellooligosaccharide-dehydrogenase }\end{array}$ & Cell wall remodelling \\
\hline \multirow[t]{3}{*}{ CE1 } & esterase domain containing & Nutrition \\
\hline & feruloyl/acetylxylan esterase & Nutrition \\
\hline & rhamnogalacturonan-acetylesterase & Nutrition \\
\hline CE12 & rhamnogalacturonan-acetylesterase & Nutrition \\
\hline CE16 & acetylesterase & Nutrition \\
\hline
\end{tabular}


Table 1. Cont.

\begin{tabular}{|c|c|c|}
\hline CE2 & acetyl-xylan esterase & Nutrition \\
\hline CE4 & chitin deacetylase & Cell wall remodelling \\
\hline CE6 & acetyl-xylan esterase & Nutrition \\
\hline GH10 & xylanase & Nutrition \\
\hline GH109 & $\alpha-N$-acetylgalactosaminidase & Glycolipids modification \\
\hline GH11 & endo-1-4- $\beta$-xylanase & Nutrition \\
\hline GH114 & $\alpha$-galactosidase & Nutrition \\
\hline GH132 & $\beta$-glucosidase & Pathogenicity \\
\hline GH15 & glucoamylase & Nutrition \\
\hline GH16 & endo- $\beta$-glucanase & Nutrition \\
\hline GH17 & glucan-1,3- $\beta$-glucosidase & Cell wall remodelling \\
\hline GH18 & chitinase & Cell wall remodelling \\
\hline GH19 & chitinase & Interaction with insects \\
\hline $\mathrm{GH} 24$ & lysozyme & Cell wall remodelling \\
\hline GH26 & endo-1,4- $\beta$-mannosidase & Cell wall remodelling, nutrition \\
\hline GH3 & $\beta$-glucosidase & Nutrition \\
\hline GH43 & arabinase/levansucrase/invertase & Nutrition \\
\hline GH45 & endoglucanase & Nutrition \\
\hline GH48 & cellulase & Nutrition \\
\hline \multirow[t]{2}{*}{ GH5 } & cellulase & Nutrition \\
\hline & exo- $\beta$-1,3-glucanase & Cell wall remodelling \\
\hline \multirow[t]{2}{*}{ GH6 } & cellobiohydrolase & Nutrition \\
\hline & endoglucanase & Nutrition \\
\hline GH72 & 1,3- $\beta$-glucanosyltransferase & Cell wall remodelling \\
\hline GH9 & cellulase & Nutrition \\
\hline GT1 & UDP-glucuronosyltransferase & Cell wall remodelling \\
\hline GT15 & $\alpha-1,2-m a n n o s y l t r a n s f e r a s e$ & Cell wall remodelling, pathogenicity \\
\hline GT17 & $\begin{array}{l}\beta-1,4 \text {-mannosyl-glycoprotein- } \beta-1,4-N \text { - } \\
\text { acetylglucosaminyltransferase }\end{array}$ & Cell wall remodelling \\
\hline \multirow[t]{2}{*}{ GT2 } & chitin synthase 2 & Cell wall remodelling \\
\hline & chitin synthase 6 & Cell wall remodelling \\
\hline GT34 & $\begin{array}{l}\text { galactomannan- } \alpha-1,6- \\
\text { galactosyltransferase/xyloglucan- } \alpha-1,6- \\
\text { xylosyltransferase / } \alpha-1,2 \text {-galactosyltransferase }\end{array}$ & Cell wall remodelling \\
\hline GT49 & $\beta-1,3-N$-acetylglucosaminyltransferase & Glycosylation \\
\hline GT68 & GT68_protein-O- $\alpha$-fucosyltransferase & Protein modification \\
\hline GT69 & $\alpha-1,3-$ mannosyltransferase & Cell wall remodelling, pathogenicity \\
\hline GT71 & $\alpha$-mannosyltransferase & Cell wall remodelling, protein modification \\
\hline GT77 & $\begin{array}{c}\alpha \text {-xylosyltransferase / } \alpha-1,3- \\
\text { galactosyltransferase/arabinosyltransferase }\end{array}$ & Protein modification \\
\hline PL1 & pectin lyase & Nutrition \\
\hline PL3 & pectate lyase & Nutrition \\
\hline PL4 & rhamnogalacturonan endolyase & Nutrition \\
\hline
\end{tabular}


Table 1. Cont.

TCDB

\begin{tabular}{|c|c|c|}
\hline TCDB ID & Family Name & Putative Role in Fungi \\
\hline 1.A.1 & The Voltage-gated Ion Channel (VIC) Superfamily & Response to stress \\
\hline 1.A.105 & The Mixed Lineage Kinase Domain-like (MLKL) Family & Programmed cell death \\
\hline 1.A.33 & $\begin{array}{l}\text { The Cation Channel-forming Heat Shock Protein-70 } \\
\text { (Hsp70) Family }\end{array}$ & Response to stress \\
\hline 1.A.4 & $\begin{array}{l}\text { The Transient Receptor Potential } \mathrm{Ca}^{2+} \text { Channel } \\
\text { (TRP-CC) Family }\end{array}$ & Response to stress \\
\hline 1.C.63 & The $\alpha$-Latrotoxin (Latrotoxin) Family & Unknown \\
\hline 1.I.1 & $\begin{array}{l}\text { The Nuclear Pore Complex (NPC) Family [formerly } \\
\text { 1.A.75] }\end{array}$ & Unknown \\
\hline 2.A.1 & The Major Facilitator Superfamily (MFS) & Nutrition, drug and metabolites transport \\
\hline 2.A.18 & Vacuolar amino acid transporter & Nutrition \\
\hline 2.A.2 & $\begin{array}{l}\text { The Glycoside-Pentoside-Hexuronide (GPH): Cation } \\
\text { Symporter Family }\end{array}$ & Nutrition \\
\hline 2.A.29 & The Mitochondrial Carrier (MC) Family & Molecules transfer to mitochondria \\
\hline 2.A.3 & $\begin{array}{c}\text { The Amino Acid-Polyamine-Organocation (APC) } \\
\text { Superfamily }\end{array}$ & Nutrition \\
\hline 2.A.4 & The Cation Diffusion Facilitator (CDF) Family & Heavy metal transport \\
\hline 2.A.7 & The Drug/Metabolite Transporter (DMT) Superfamily & Drug/ion resistance, cell wall remodelling \\
\hline 3.A.1 & The ATP-binding Cassette (ABC) Superfamily & Essential for many processes in the cell \\
\hline 3.A.16 & $\begin{array}{l}\text { The Endoplasmic Reticular Retrotranslocon (ER-RT or } \\
\text { ERAD) Family }\end{array}$ & Protein degradation \\
\hline 3.A.2 & $\begin{array}{c}\text { The H+- or Na+-translocating F-type, V-type and A-type } \\
\text { ATPase (F-ATPase) Superfamily }\end{array}$ & Decomposition of ATP to ADP \\
\hline 8.A.28 & The Ankyrin (Ankyrin) Family & Unknown \\
\hline 8.A.5 & The Voltage-gated $K+$ Channel $\beta$-subunit $(\operatorname{Kv} \beta)$ Family & Unknown \\
\hline 8.A.8 & The Phosphotransferase System HPr (HPr) Family & Unknown \\
\hline 8.A.85 & The Guanylate Cyclase (GC) Family & Unknown \\
\hline 9.A.1 & The Non ABC Multidrug Exporter (N-MDE) Family & Drug resistance \\
\hline 9.A.3 & $\begin{array}{l}\text { The Retromer Assembly Apparatus (RetromerAA) } \\
\text { Family }\end{array}$ & Protein recycling \\
\hline 9.A.63 & $\begin{array}{l}\text { The Retromer-dependent Vacuolar Protein Sorting } \\
\text { (R-VPS) Family }\end{array}$ & Intracellular sorting \\
\hline
\end{tabular}



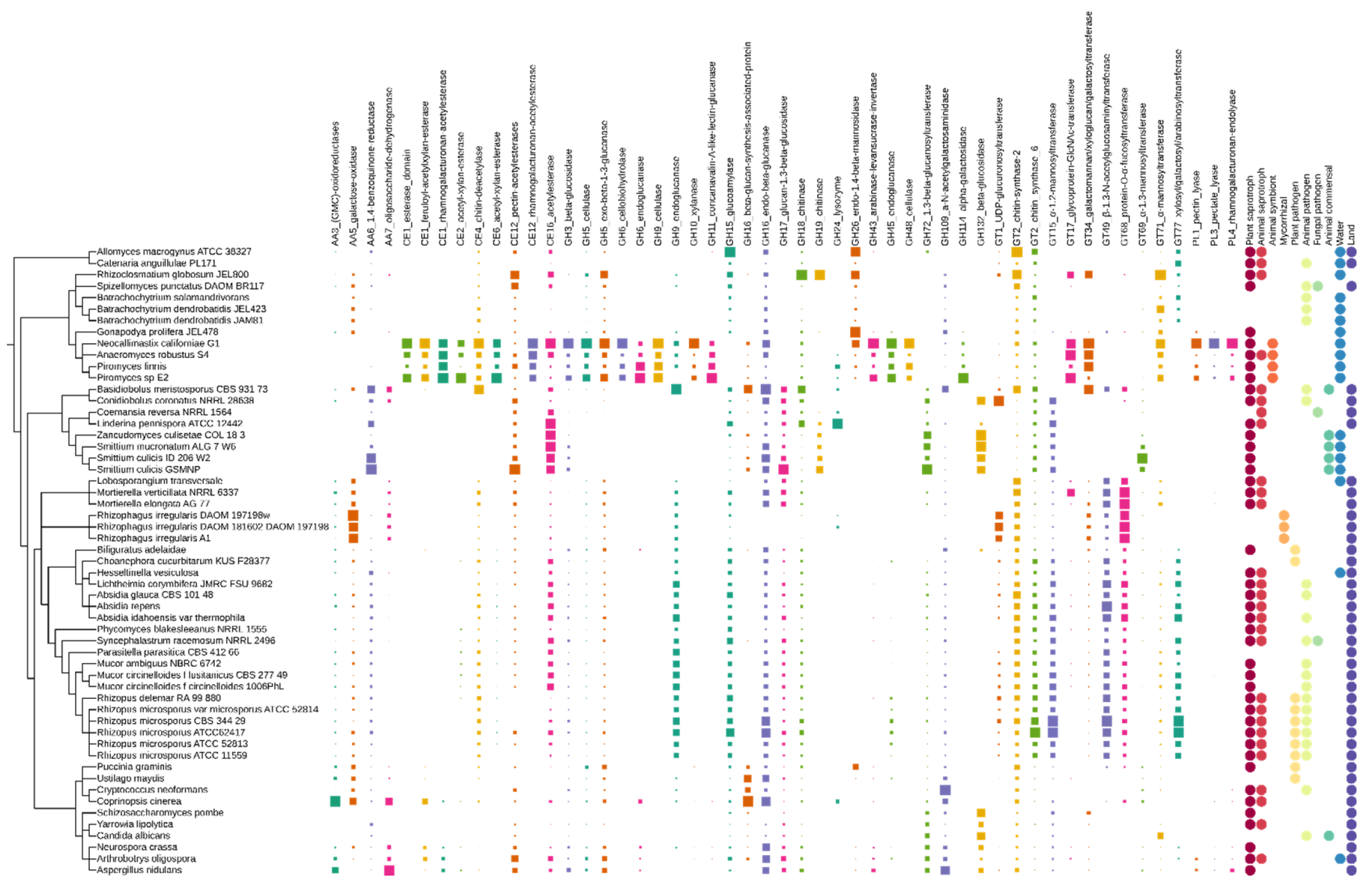

Figure 1. Distribution of adaptasome CaZymes within early-diverging fungi. The presence of proteins belonging to a particular family is marked with squares of size corresponding to their copy number. Fungal ecology features are shown as circles.

\subsection{Carbohydrate-Active Enzymes Families (CAZymes)}

The selected 43 CAZy families have at least 58 biological functions in fungi (Table 1, Figure 1). Most of the CAZymes play a role in either the decomposition of plant origin organic matter or in the remodelling of the fungal cell wall. In addition, we can also distinguish proteins associated with post-translational protein modification, acting as a virulence factor during the infection of animals, and involved in the neutralization of the host's defence. One of the adaptasome CAZymes putatively acts on lipids. On one hand it is known that glycolipids play a role in diverse interactions; on the other, (glyco)lipid composition varies between fungi, impeding exact function predictions.

The CAZy database is organized according to enzymatic classes into auxiliary activity (AA), carbohydrate esterases (CE), glycoside hydrolases (GH) and glycosyl transferases (GT) and we adhere to this classification.

\subsubsection{CAZymes with Auxiliary Activity (AA)}

The adaptasome harbours four families of redox enzymes that act in conjunction with other CAZymes (auxiliary activity (AA)). Three out of four AAs are ligninolytic enzymes (AA3, AA5 and AA6). AA3 glucose-methanol-choline (GMC) oxidoreductases are widespread in fungi and catalyse the oxidation of either alcohols or carbohydrates with the concomitant formation of hydrogen peroxide or hydroquinones. Hydrogen peroxide is required for the proper function of lignin degradation peroxidases. This compound may also be provided by copper radical oxidases from the second family AA5 [32]. The third group of AA enzymes associated with lignin utilization is AA6 (1,4-benzoquinone reductases). The activity of this protein was described in the brown rot fungus Gloeophyllum trabeum. This fungus uses a quinone redox cycle to generate extracellular Fenton reagent, a 
key component of its biodegradative system [33]. 1,4-benzoquinone reductases are not only involved in the degradation of aromatic compounds, but also in the protection of fungal cells from reactive quinone compounds. AA6 enzymes are used by entomopathogenic fungi to detoxify quinone secreted by the host. This kind of arms race was observed between the beetle Tribolium castaneum and fungus Beauveria bassiana [34]. The biggest expansion of AA3 was observed in saprotrophic Basidiomycota-Coprinus cinerea. The laccase activity was experimentally demonstrated for this species [35]. All above-mentioned AAs (AA3, AA5 and AA6) were also present in Mucoromycota, as previously shown by Kameshwar and Qin [36], and the expansion of AA5 was observed in arbuscular mycorrhizal fungi Glomeromycotina. However, Glomeromycotina are considered as weak degraders [37].

The AA7 family harbours oligosaccharide flavo-oxidases which can transfer electrons to lytic polysaccharide monooxygenase and, consequently, fuel cellulose degradation [38]. Homologs of AA7 were found in plants, fungi and fungi-like microorganisms. A huge abundance of AA7 genes was revealed in phytopathogenic fungi and Oomycota [38]. We also observed an increased occurrence of AA7 homologs in saprotrophic and entomopathogenic fungi.

\subsubsection{Carbohydrate Esterases (CE)}

Enzymes from the carbohydrate esterases (CE) class occur especially frequently in anaerobic chytrids. Eight out of nine adaptasome $\mathrm{CE}$ families are responsible for plant biomass degradation [39,40]. The abundance of carbohydrate esterase enzymes in Neocallimastigomycota correlates with their lifestyle as digestive tract symbionts of large herbivores [41]. The families CE2, feruloyl acetylxylan esterase (CE1), and uncharacterized esterases (CE1) show high sequence similarity to bacterial sequences (CE1 feruloyl acetylxylan esterase-ORY83980.1 to MBQ4034677.1 with similarity 57.71\%; CE1 uncharacterized esterases-ORY24510.1 to WP_092476704.1 61.76\%; CE2-OUM64776.1 to MBQ1538045.1 $48.01 \%$ ) which is consistent with previously documented HGT in this lineage [42]. These transferred genes were duplicated several times and paralogs were retained likely because of environmental requirements.

CE4 chitin de- $N$-acetylases (CDAs) hydrolyse chitin, chitosan, and chitooligosaccharides and are responsible for fungal cell wall remodelling, which is especially important for pathogens during interactions with the host [43-45]. Interestingly, CE4 enzymes also play a role in symbiotic interaction between terrestrial fungi and their bacterial symbionts [46]. One might speculate that the abundant fungus-bacteria interactions in the aquatic environment of the gut may also be facilitated by the activity of CE4 proteins.

\subsubsection{Glycoside Hydrolases (GH)}

Glycoside hydrolases (GH) have an established role in fungal nutrition, particularly in plant biomass degradation and cell wall remodelling [40,47]. The adaptasome encompasses $20 \mathrm{GH}$ families holding 25 different biological functions, inferred from protein databases and the literature. Neocallimastigomycota, Zoopagomycota, and Mucoromycota have lineage characteristic patterns of the expansion and contraction of these $20 \mathrm{GH}$ families. More than half (13) of the identified enzymes are associated with the decomposition of plant biomass. These are xylanase (GH10, GH11), galactosidase (GH114), glucosidase (GH132, GH3), glucoamylase (GH15), glucanase (GH16, GH45, GH6), lysozyme (GH24), mannosidase (GH26), cellulase (GH48, GH5, GH9), and cellobiohydrolase (GH6). Almost all families were previously described in fungi and found to be associated with a saprotrophic lifestyle $[48,49]$. Mucoromycota are often considered unable to degrade cellulose, but more recent experiments have shown cellulase activity in this lineage [50]. The identification of cellulase expansions in GH48, GH5 and GH9 suggests that the degrading capabilities of Mucoromycota could be broader than expected. Two of the identified CAZyme families have no obvious function-arabinase/levansucrase/invertase (GH43) and lysozyme (GH24) (UniProt-based annotation, prediction was made based on non-fungal organisms). The first enzyme is especially common in anaerobic chytrids and was likely acquired via 
HGT from bacterial donors (OUM61724.1 to SER94208.1 57.27\%). A study on the GH43 family showed the existence of 37 subfamilies, including Neocallimastigomycota-specific clades [51], all of them involved in the degradation of plant biomass. Proteins assigned to family GH24 have a Phage_lysozyme (PF00959) domain, which in phage T4 endolysin has lysozyme activity—it degrades host peptidoglycans [52]. Our results show the highest abundance of lysozymes GH24 in Linderina pennispora, Piromyces sp., and Coprinopsis cinerea.

Eight glycoside hydrolase families are involved in cell wall remodelling: galactosidase (GH114), glucosidases (GH17, GH132), chitinases (GH18, GH19), lysozyme (GH24), glucanase (GH5), and glucanosyltransferase (GH72) $[47,53]$. The cell wall and its remodelling is crucial for survival and strictly associated with interaction with the environment. Remodelling events are important during interaction with a variety of partners. They enable pathogens to interact with plant host tissues [44], the interaction between mycorrhizal partners [54], and immune evasion during infecting animals [55]. Some GH114 members have an additional function: they can disrupt microbial biofilms (e.g., Ega3 from Aspergillus fumigatus is an endo- $\alpha$-1,4-galactosaminidase) [56].

Two changing glycoside hydrolases are probably used by fungi against animal organisms. Chitinase from family GH19 seems to occur only in early fungal phyla such as Microsporidia, Chytridiomycota, and Zoopagomycota (domain distribution in Pfam database). All these fungi are well known from their development on chitin-rich substrates [57]. A described homolog of GH19 in fungi was observed in Nosema bombycis and classified as type IV chitinases [58]. Such a distribution may point to early branches of FToL, having their own characteristic workshop for cell wall modification, but not only this. Our results show the expansion of these enzymes in Zoopagomacota greater than in other taxa. We hypothesize that GH19 chitinases are used to fight either other fungi in occupied niches (they are known to have antifungal activity [59]) or the chitin armour of the animal host/prey (e.g., insects). This second assumption may also be true for the chytrid Rhizoclosmatium globosum-the JEL800 strain was isolated from shrimp chitin bait (JGI website info).

GH132 $\beta$-glucosidase, which is also involved in cell wall biogenesis, plays a role as a virulence factor. This enzyme was described as protein Sun 41 in Candida albicans. Sun41 was proven to promote proper cell wall structure (by having a catalytic role in cell wall modification) and enables biofilm formation. Therefore, Sun41 is required for disseminated infection [60]. The GH132 family has the greatest expansion in Zoopagomycota and yeasts.

\subsubsection{Glycosyl Transferases (GT)}

Most fungal genomic studies refer to the abundance of selected glycosyl transferases (GT) and the adaptasome consistently contains ten GT famlies. Most of these protein families have the greatest expansions in Mucoromycota (GT2, GT15, GT49, GT68, GT77).

UDP-glucoronosyltransferase GT1 occurs frequently in Mucoromycota and Entomophtoromycota. This enzyme was widely described in humans and other mammals, but its function in fungi remains unclear. Due to the composition of the Mucoromycota cell wall (high contents of galacturonic acid) we hypothesize that it is associated with the remodelling of this structure [61]. Family GT49 also can be related to the modification of uronic acids. Proteins from this family can be found as $\beta-1,4$-glucuronyltransferase in animals, Capsaspora, and Choanozoa, which indicates their ancestral character. We found representatives of this family predominantly in Mucoromycota. It is worth noting that enzymes from GT49 are involved in the pathway of glycosphingolipids biosynthesis. We hypothesize that GT49 takes part in glycocalyx formation [62]. GT49 is known in humans as LARGE protein [63].

The GT2 family contains diverse transferases; among others, the fungal chitin synthases seem to occur in variable copy numbers across taxa. Chitin synthase II is widespread among FToL, and is considered essential for most fungi [64]. All analysed isolates from diverse lineages, except Kickxellomycotina, had several copies of this synthase. Kickxellomycotina representatives have just a single chitin synthase II and live with arthropods, which 
happen to have a chitin cuticle. This raises questions regarding whether these two facts are related.

Chitin synthase VI displays a complex domain architecture consisting of Chitin_synth_2 (PF03142), Myosin_head (PF00063), Cyt_b5 (PF00173), and DEK_C (PF08766) domains in various combinations. Three clades of terrestrial fungi show lower copy numbers of chitin synthase VI than the rest: Mortierellomycota, Glomeromycota, and Dikarya.

GT15 $\alpha-1,2-$ mannosyltransferase is involved in the O-glycosylation of the cell wall and secreted proteins in Schizosaccharomyces pombe (encoded by omh1 gene) [65]. In our study, the GT15 family shows expansion in Zoopagomycota and Mucoromycota, which have a different cell wall glycan ornamentation than S. pombe; consequently, the question of the mannosylated substrate remains open. GT69 $\alpha-1-, 3-$ mannosyltransferase homolog from Cryptococcus neoformans was described as part of the polysaccharide capsule's biosynthesis pathway [66]. In our results, the highest occurrence of GT69 proteins was observed in Smittium spp.

Other proteins responsible for the modification of proteins are $\alpha-1,3-$ mannosyltransferase (GT71) and protein-O- $\alpha$-fucosyltransferase (GT68). GT71 has known homologs in yeast, where they are encoded by mnn genes [67]. Protein-O- $\alpha$-fucosyltransferase is responsible for protein modification by O-fucosylation. This kind of modification is known from mammals, but to this day there is no information about this process in fungi [68]. GT68 enzymes show outstanding expansion in Mucoromycota, which are characterized by high fucose content in their cell wall $[61,69]$. GT77 also contains proteins probably associated with protein modifications. Among this family, we observed three domain architectures: composed only by Nucleotid_trans (PF03407) domain, or by Nucleotid_trans domain accompanied by GDP_Man_Dehyd (PF16363) or Branch (PF02485) domain.

Two glycosyltransferase families with similar distribution-GT17 ( $\beta$-1,4-mannosylglycoprotein- $\beta$-1,4- $N$-acetylglucosaminyltransferase) and GT34 ( $\alpha$-1,2-galactosyltransferase) - are related to the fungal cell wall [47]. These proteins are abundant in Neocallimastigomycota, and GT34 also in Basidiobolus meristosporus.

Three classes of polysaccharide lyases, pectin lyase (PL1), pectate lyase (PL3), and rhamnogalacturonan-endolyase (PL4), are included in the adaptasome. PL proteins are highly abundant in Neocallimastigomycota, but also present in other taxa with plant biomass degradation ability. PL are enzymes typical for fungi, with potential for plant polysaccharide utilization [70].

3.1.5. CAZyme Distribution and Abundance Can Be Linked to the Ecology of Particular EDF Lineages

The anaerobic fungi grouped in Neocallimastigomycota show expansions of many protein families in comparison with other fungal taxa. The majority of these duplicated gene families encode enzymes dedicated to the decomposition of plant tissues including AA3, AA5, AA6, CE1, CE12, CE16, CE2, CE6, GH10, GH11, GH114, GH15, GH16, GH26, GH3, GH43, GH45, GH48, GH5, GH6, GH8, PL1, PL3, and PL4. One of the reasons behind the peculiar pattern of CAZymes in Neocallimastigomycota is the documented massive horizontal gene transfer from bacteria to these fungi. They thrive with an uncommon life for a fungus, inhabiting an anaerobic environment of the herbivore digestive tract. This particular niche imposes a strong selective pressure on its dwellers. The HGT events allowed anaerobic chytrids to successfully adapt to this ecological challenge [42]. The opposite pattern is present in the case of other chytrids, which presumably lost several families of CAZymes responsible for $\beta$-glucan and mannose modification. A similar situation with contracted CAZyme families may be observed in Saccharomycotina yeast, and it is probably related to a general tendency towards genome reduction in this lineage. Despite this, yeasts show distinctive expansions of families GH132, GH6, and GH72, which are involved in cell wall modification and biofilm formation. Other fungi with specific expansions of CAZymes are Bifiguratus adelaidae and Rhizoclosmatium globosum. Losses of CAZymes may also be observed in Glomeromycotina, which lack some of the families of plant biomass-degrading 
enzymes (acetyl-xylan-esterase CE2 and CE6). Such losses are characteristic for plant mycorrhizal symbionts [71]. The phylum Zoopagomycota seems to have lost several families of CAZymes which can be linked to the reduced ability to degrade plant biomass. On the other hand, these animal-related fungi have their unique expansions of GH19-related chitinases and AA6 benzoquinone reductase. Discrepancies in CAZyme abundance between Basidiobolus meristosporus and Conidiobolus coronatus are in line with documented ecological and genomic differences between Basidiobolales and Entomophtorales (see Figure 1).

\subsection{Peptidases}

The adaptasome encompasses nineteen MEROPS families of peptidases with twentysix different associated biological activities (Table 1, Figure 2). The contribution of identified peptidases to fungal ecology has been described only for seven of the nineteen selected protein families. Aspartyl proteases (including A01 family pepsins) and metalloproteinases M36 are well known from studies on Batrachochytrium sp. pathogenicity [72]. Both B. dendrobatidis and B. salamandrivoras have a reported great expansion of M36 metalloproteases compared with a free-living chytrid Spizellomyces punctatus [73]. Our results confirm this trend. Pepsin A01 and subtilisin S08A proteases were described as ecologically relevant for ectomycorrhizal fungi [74]. A01 proteases also show expansion in other taxa associated with plants and saprotrophic species. The lowest copy number of A01 and S08A is observed in animal-associated Zoopagomycota and rumen symbiotic chytrid Neocallimastigomycota.
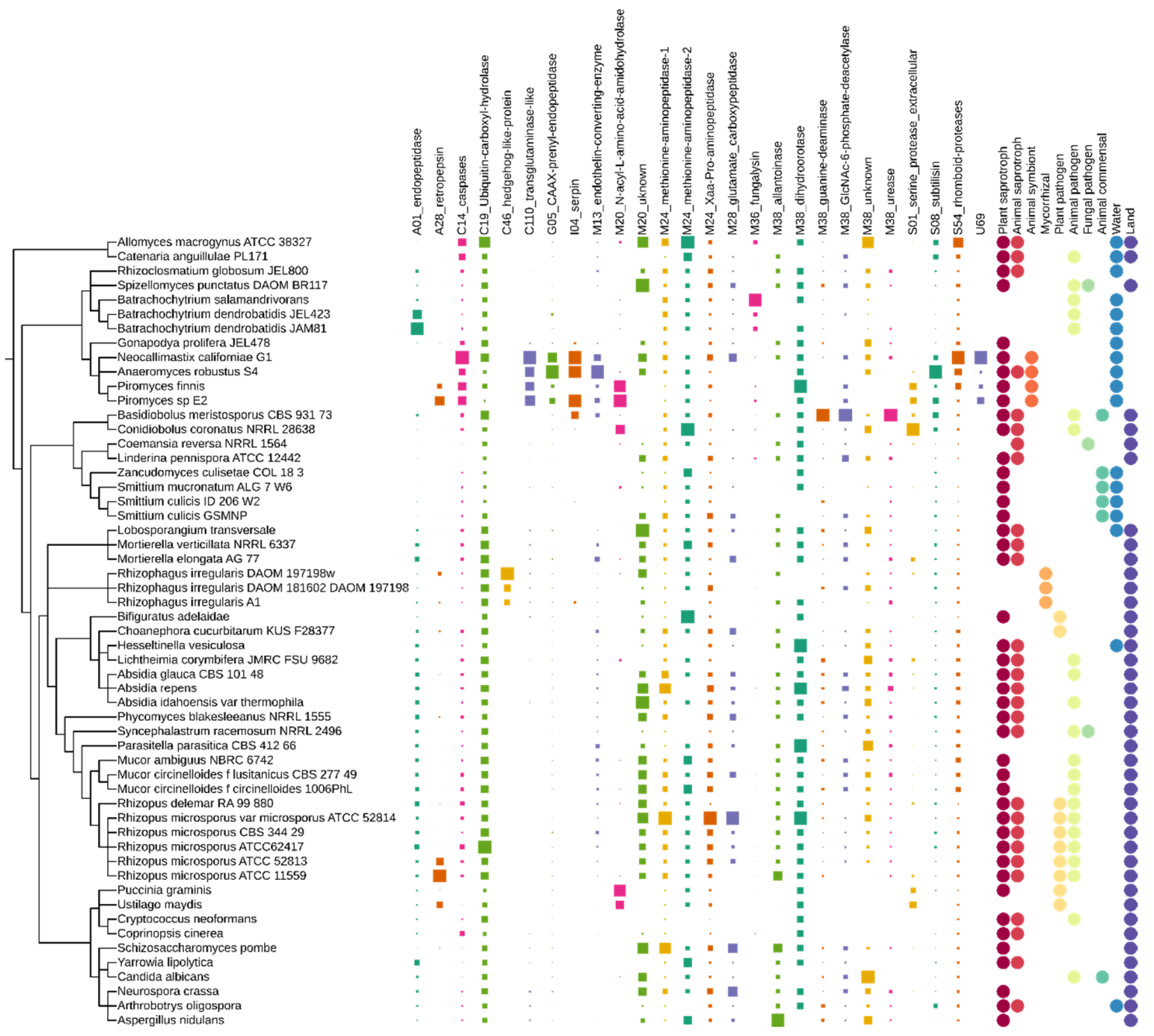

Figure 2. Distribution of adaptasome peptidases within early-diverging fungi. The presence of proteins belonging to a particular family is marked with squares of size corresponding to their copy number. Fungal ecology features are shown as circles. 
Families uncharacterized in fungi were annotated functionally based on information obtained from either animal or bacterial models. The function of two families, M20 and M38, remains fully unknown-searches against protein annotation databases (pfam, orthodb, uniprot, and blast) provide information solely on the assignment to a given MEROPS family.

\subsubsection{Aspartic Peptidases}

We identified two families of aspartic peptidases in the adaptasome: A01 and A28. Protein domain analysis showed that aspartyl peptidases from the A28 family are unannotated retro peptidases responsible for the cleavage of the LTR retrotransposon pol polyprotein. Retroviral aspartic peptidases have been previously reported as problematic in sequencebased classification [75], many of them belonging to A2 and A11 families. The A28 family has not been annotated in regard to retropepins so far. These proteins are present in great copy numbers in diverse taxonomic groups (Neocallimastigomycota, Glomeromycotina, $\mathrm{Mu}$ coromycotina, Dikarya) (Figure 2). They show the greatest expansion in fungi associated with plants, consistent with previous reports on LTR retrotransposon abundance [76]. The presence of transposable elements in our result may be another indication that TE play a role in the adaptation of fungi to the environment [77]. It is also plausible that retropepins were domesticated and gained novel functions. On the other hand, the presence of retropepsins in the proteome can be a consequence of inefficient transposon masking prior to gene calling. We found that the number of retropepsins in the proteome does not correlate with the number of identified LTR retrotransposons in the genome.

\subsubsection{Cysteine Peptidases}

Three families of cysteine peptidases belong to the adaptasome. Family C14 groups various caspases. Caspases are involved in programmed cell death (PCD). In fungi, PCD has multiple manifestations. This process takes place during reproduction and aging, but it is also a response to contact with some environmental conditions, such as nonself-recognition or stress [78]. The ancient fungal lineages Neocallimastocomycotina and Blastocladiomycota show the highest copy numbers of C14 caspases in our dataset.

Ubiquitin carboxyl hydrolases C19 are present in all studied fungal proteomes, including the product of creB gene in Aspergillus nidulans. This peptidase is a part of the regulatory network controlling carbon source utilization, and also plays a role in the response to carbon starvation $[79,80]$. In Trichoderma reesei, creB was proven to be associated with cellulase expression [81]. Ubiquitin carboxyl hydrolases C19 were particularly abundant in aquatic EDF and Mucromycota.

Homologs of family C46 show huge expansion in Glomeromycotina and do not occur in any other of the analysed fungi. These proteins share a common architecture of two domains: AIG1 (PF04548) and Hint (PF01079), as described previously [82]. R. irregularis C46 peptidases are believed to be involved in the putative mating response, which was studied in planta [82]. The Hint domain is also an element of inteins-mobile, self-splicing elements that interrupt proteins. Hint performs autoproteolytic reactions, having activity at the N- or C-terminus of an intein. Hint inteins were found both in metazoans and Amorphea, Archeaplastida, Cryptista, and SAR. [83].

The C110 family contains homologs of proteins coded by Schizosaccharomyces pombe gene png1. These enzymes belong to the peptide:N-glycanases responsible for the deglycosylation of misfolded glycoproteins in a system called endoplasmic-reticulum-associated degradation (ERAD) [84]. C110 proteins are especially numerous in Neocalimastigomycota, which are known to have heavily glycosylated CAZymes [85].

\subsubsection{Glutamic Peptidases}

Proteins from family G05 (previously M79) show similarity to type II CAAX prenyl endopeptidase. Prenylation is the process of the addition of hydrophobic molecules to a protein. The prenyl group is attached to the CAAX motif in protein, which is crucial for the 
function and membrane targeting of many eukaryotic proteins [86]. These peptidases are present in all studied fungi, but are more copious in anaerobic chytrids.

\subsubsection{Inhibitors}

Serpins (I04) constitute the single family of peptidase inhibitors in the adaptasome. Serpins are present mostly in older taxa, such as Neocalimastigomycota and Entomophthtoromycotina. These proteins have two protein domains, CBM_10 and Serpin. Inhibitors with such domain architecture were described in anaerobic fungi Piromyces and called celpins (from "cellulosomal seprin"). Celpins probably protect the cellulosome against proteolytic degradation by proteinases from the surrounding environment (herbivore digestive track and coexistent bacteria). Celpins were observed in the cellulosome-producing thermophilic bacterium Clostridium thermocellum [87]. This observation points at a likely history of the horizontal acquisition of these genes by anaerobic fungi ancestors.

\subsubsection{Metallo Peptidases}

Peptidases from family M13 occur in all fungal taxa and are predicted to be secreted. They have the biggest expansion in anaerobic chytrids and fewer copies in Zoopagomycota and Dikarya. Bacterial M13 metallopeptidases are endopeptidases with broad substrate specificity. Taken together, these proteins probably play a nutritional role [88].

Two groups of homologs in family M20 were recognized, forming two separate clades on the phylogenetic tree. The first clade contains homologs of Aminoacylase-1, coded in humans by the acy 1 gene. Acy 1 plays a role in the breakdown of acylated amino acids generated during protein degradation. In bacteria, homologs of Acy1 are implicated in the biosynthesis of arginine, lysine, and components of the cell wall [89]. Homologs from the second clade do not show a similarity to characterized proteins.

Family M24 groups peptidases with different molecular targets, which function as: methionine aminopeptidases (MAP1/MAP2 in Saccharomyces cerevisiae) and Xaa-Pro aminopeptidase. MAP1 and MAP2 are known to play an essential role in the maturation of a nascent polypeptide during translation. The deletion of map 1 and map 2 genes in yeast is lethal [90]. Other homologs from this family show similarity to Xaa-Pro aminopeptidase pepP from Aspergillus nidulans. In animals, this enzyme is involved in the utilization of bradykinin [91]. In fungi, these proteins probably play a role in nutrition. In our study, MAP1 was especially abundant in Absidia spp. and Schizosaccharomyces pombe. MAP2 occurs in the greatest copy number in Blastocladiomycota, Conidiobolus coronatus, and Endogonales. Proteins with Xaa-Pro-aminopeptidase activity seem to be more common in Mucorales than in other taxa.

We identified M28 peptidases in almost all taxa with the exclusion of Glomeromycotina and Basidiomycota. However, the function of these proteins remains unknown in fungi. The most similar proteins to our sequences are glutamate carboxypeptidase II (GCPII) and transferrin receptor protein 1. GCPII has been well studied for human and mouse homologs. In humans, this enzyme is expressed predominantly in the central nervous system - where it hydrolyzes one of the neurotransmitters-in the prostate, small intestine, and kidney [92]. Transferrin is one of the key proteins to regulate iron homeostasis in vertebrate cells [93].

Metalloproteinases M38 are particularly abundant in Blastocladiomycota, chytrids, Zoopagomycota, and Mucoromycota. This family has been divided into subfamilies and our results contain six subfamilies. Four of them are related to the uric acid degradation pathway. Urease has conserved roles in promoting fungal infections. It was shown that urease is required for the full virulence of Cryptococcus neoformans and Coccidioides posadasii in animal models. The activity of urease during fungal infection is important in multiple ways: it is linked with providing nitrogen for the pathogen, and urea is metabolized to ammonia which takes part in damaging host tissues and interfering in the functions of phagocytes [94]. The activity of urease in fungal infections led to the development of urease tests for diagnostic purposes. We observed the greatest abundance of urease in Basidiobolales. 
The remaining two subfamilies are amidohydrolases with unknown functions and proteins similar to $N$-acetylglucosamine 6-phosphate deacetylase (nagA). This enzyme takes part in utilizing a carbon source, $N$-acetylglucosamine (GlcNAc), which is a major component of structural polymers in bacteria, plants, and animals. GlcNAc is also known to have a stimulatory effect on filamentation in Ascomycota [95]. In our study, they were mostly abundant in Blastocladiomycota, Basidiobolales, and Mucoromycota.

\subsubsection{Serine Peptidases}

The adaptasome includes tree serine proteases families: S01 (chymotrypsin-like), S08 (subtilisin), and S54 (rhomboid). Relationships between these proteins and fungal ecology were previously described for pathogenic [96] and saprotrophic lifestyles [97]. Next, researchers confirmed the high abundance of S01 proteins in the proteomes of pathogenic fungi and S08 in proteomes of soil/dung fungi [98]. Our result also indicates a high occurrence of S08 homologs in anaerobic fungi-it may be due to environmental requirements in the herbivore digestive tract. The rhomboid serine protease (S54) family includes yeast proteins Pcp1/Rbd1 and Rbd2. Members of the rhomboid family were divided into five subfamilies of which RhoA, RhoD and PARL are present in fungi. Their number was shown to correlate positively with a pathogenic lifestyle in fungi [98], and consistent with the prediction, A. fumigatus RbdB was critical for virulence [99].

\subsubsection{Unknown Peptidases}

Unknown family U69 groups CAZymes rather than peptidases. A representative of this family, Cthe_2159 from Clostridium thermocellum, has been characterized structurally, showing similarities with polysaccharide lyases. It is also the first representative of a novel family of cellulose and/or acid-sugar binding beta-helix [30]. This observation shows that protein family classification is an ongoing process, with reclassifications happening constantly.

\subsection{Transporters}

Twenty-four classes of transporters belong to the adaptasome. TCDB proteins show four characteristic distribution patterns. The first one includes expansions of families involving essential transporters such as MSF (major facilitator superfamily), DMT (drug/metabolite transporters), transporters associated with the uptake of nutrients, ion channels and others, covering most of the analysed fungal lineages (Figure 3). These transporter classes are particularly abundant in Mucoromycota and Basidiobolales. The second pattern can be defined as Glomeromycotina-specific expansions of classes: mixed lineage kinase domain-like, nuclear pore complex, phosphotransferase system HPr, and guanylate cyclases. The third pattern is limited to anaerobic chytrids - these are families with an ankyrin domain. The last group of transporter expansions happened in the mutualists Neocallimatigomycotina and Glomeromycotina-VIC (voltage-gated ion channels), TRP-CC (the transient receptor potential Ca ${ }^{2+}$ channels), and Hsp70. The interpretation of the transporter constituents of the adaptasome is highly non-trivial due to the limited knowledge of transporters overall. TCDB often describes a particular copy of a given transporter in a very detailed cell/tissue/structure which is not generalizable or even transferable from human to fungi. It is already known that transporters and receptors can be recruited to highly diverged and sophisticated roles. In this section, we will summarize what is known on the transporter families, starting from the best studied and characterized in fungi to the least recognized in the literature. 

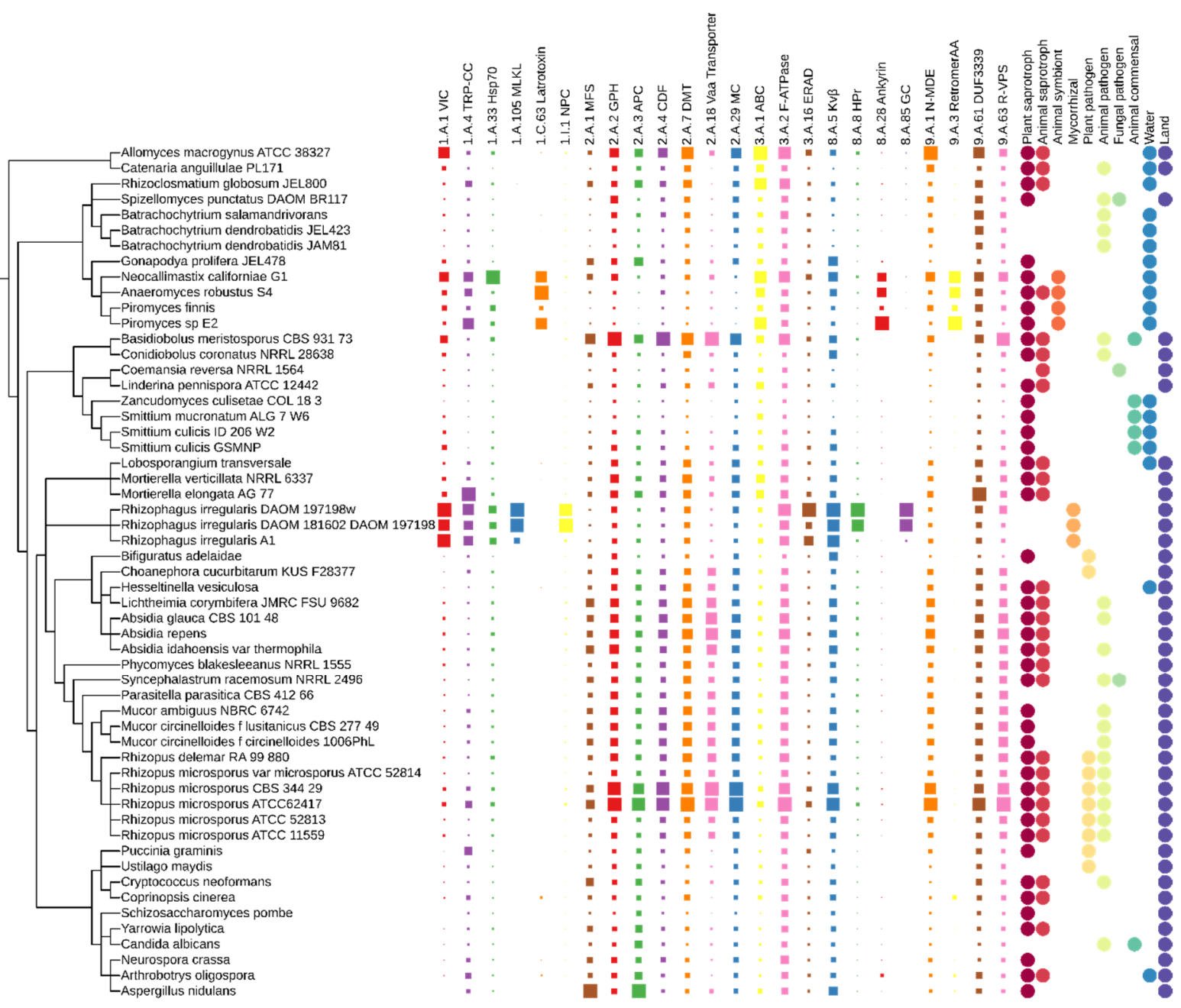

Figure 3. Distribution of adaptasome transporters within early-diverging fungi. The presence of proteins belonging to a particular family is marked with squares of size corresponding to their copy number. Fungal ecology features are shown as circles.

\subsubsection{Essential Transporters}

Not surprisingly, the adaptasome encompasses the most common transporters, crucial for the functioning of organisms, such as MFS, ABC, DMT, VPS and other vacuolar transporters. Fungal homologs of these transporters have documented roles in drug resistance and nutrition. They were particularly abundant in Blastocladiomycota, chytrids, Basidobolales, and Mucoromycota and had a limited number of homologs in Dikarya and Kickxellomycotina.

The major facilitator superfamily (MFS) (2.A.1) are ubiquitous membrane proteins with millions of sequenced members. The MFS family was originally believed to function primarily in the uptake of sugars, but subsequent studies revealed that drugs, metabolites, oligosaccharides, amino acids and oxyanions were all transported by MFS family members [100]. In fungi there are known MFS transporters responsible for the transport of glucose [101], fructose [102], galactose and lactose [103], maltose [104], cellobiose [105] and more. Taken together, MFS transporters are essential for fungal nutrition. EDF show expansions of this kind of transporter, especially in rapidly growing sugar fungi Basidiobolales and Mucoromycota.

The ATP-binding cassette (ABC) superfamily (3.A.1) is one of the largest and possibly one of the oldest gene families. These ubiquitous transporters are more commonly closer to the root of FToL-in Blastocladiomycota and chytrids, but also in Mortierella spp. ABC transporters have been characterized from both prokaryotes and eukaryotes; they are essential for many processes in the cell [106]. There are many examples of characterized 
fungal $\mathrm{ABC}$ transporters: Mdr1 protein, responsible for Aspergillus fumigatus drug resistance [107]; S. cerevisiae Pxa1, involved in the import of long-chain fatty acids from cytosol to peroxisomes; Pdr18 that inserts ergosterol into the membrane; vacuolar metal resistance and drug resistance protein Ycf1 [108]; and more.

The drug/metabolite transporter (DMT) superfamily (2.A.7) is a complex ensemble of 31 families, and fungal homologs are present in 11 of them (TCDB website info). DMT are abundant in Blastocladiomycota, Chytridiomycota, and Mucoromycota. The triose-phosphate transporter (TPT) family (2.A.7.9) members are derived from the inner envelope membranes of chloroplasts and non-green plastids of plants. However, homologs are also present in yeast, but their function is unknown [109]. The UDP- $N$-acetylglucosamine: UMP antiporter (UAA) family (2.A.7.10) proteins are found in the Golgi apparatus and the endoplasmic reticulum of eukaryotic cells. Yea4 protein from S. cerevisiae is a sugar transporter required for cell wall chitin synthesis [110]. The same in-cell localization is characteristic for the UDP-galactose: UMP antiporter (UGA) family (2.A.7.11). Hut1 S. cerevisiae protein from this family is involved in the maintenance of an optimal environment for the folding of secretory pathway proteins in the endoplasmic reticulum [111]. The GDP-mannose:GMP antiporter (GMA) family (2.A.7.13) includes fungal transporters involved in hyphal formation, e.g., Vrg4 from C. albicans [112]. Fungal proteins were also observed in family 2.A.7.16 (the GDP-fucose transporter (GFT) family) [113]. The thiamine pyrophosphate transporter (TPPT) family (2.A.7.24) includes yeast protein Thi74, which may be involved in thiaminediphosphate transport across the mitochondrial membrane [114]. The NIPA $\mathrm{Mg}^{2+}$ uptake permease (NIPA) family (2.A.7.25) groups proteins acting as $\mathrm{Mg}^{2+}$ transporters, which can also transport other divalent cations such as $\mathrm{Fe}^{2+}, \mathrm{Sr}^{2+}, \mathrm{Ba}^{2+}, \mathrm{Mn}^{2+}$ and $\mathrm{Co}^{2+}$ but to a much lesser extent than $\mathrm{Mg}^{2+}$. This family includes two uncharacterized fungal homologs [115]. The $\mathrm{Ca}^{2+}$ homeostasis protein (Csg2) family (2.A.7.27) has only one described protein, Csg2 from S. cerevisiae. Csg2 is required for calcium regulation-it may regulate the calcium level by a non-vacuole organelle. It is worth noticing that this protein also plays a role in ceramide synthesis [116]. The solute carrier 35G (SLC35G) family (2.A.7.28) includes one fungal homolog which contains the HeLo (PF14479) domain. HeLo is known for a prion-inhibitory effect and is found exclusively in the kingdom Fungi [117]. Bacterial/archaeal transporter (BAT) family (2.A.7.2) includes two uncharacterized fungal sequences. The last family containing fungal homologs is the uncharacterized DMT-4 (U-DMT4) family (2.A.7.32) - the function of the included proteins remains unknown.

The retromer-dependent vacuolar protein-sorting (R-VPS) family (9.A.63) has several expansions in Basidiobolales and Mucoromycota. The retromer complex is a trafficking assembly composed of at least three proteins-Vps26, Vps29 and Vps35-in Saccharomyces cerevisiae. Proteins from this family play a role in the intracellular sorting and delivery of soluble vacuolar proteins [118]. The VPS system in fungi is one of the main routes of vesicle formation, essential for autophagy and pathogenesis $[119,120]$.

Family 2.A.18 (vacuolar amino acid transporter) include fungal amino acid permeases, e.g., PcMtr protein from Penicillium chrysogenum. These proteins are not limited to Dikarya and are found abundantly in Basidiobolales and Mucoromycota. Fungal permeases are responsible for the uptake of amino acids, which can serve as a nitrogen and carbon source. They may also be involved - such as Mtr-type transporters—in the uptake of signalling molecules [121].

\subsubsection{Less Frequent Fungal Transporters}

Transporters with some characterized fungal homologs. These families are essential transporters such as VIC, ion channels, nuclear pore complexes, transporters involved in the uptake of nutrients, mitochondrial carriers, drug transporters, and others.

The voltage-gated ion channel (VIC) superfamily (1.A.1) occurs abundantly in Neocallimastigomycota and Glomeromycotina. There are two described VIC proteins in fungi, both from Saccharomyces cerevisiae: TOK1, which is an outwardly rectifying $\mathrm{K}+$ channel with a 
unique structure and function [122], and calcium channel protein Cch1, which is essential for a full response to ion stress [123].

The transient receptor potential $\mathrm{Ca}^{2+}$ channel (TRP-CC) family (1.A.4) proteins are involved in the response to changes in the environment and seem to be duplicated in the symbiotic fungi Neocallimastigomycota and Glomeromycotina. Calcium ions, present inside all eukaryotic cells, are important second messengers in the transduction of biological signals. Four proteins from this family were described in yeast. YVC1 protein is required for the release of calcium ions from the vacuole during hyperosmotic shock [124]. FLC1 and FLC2 (Flavin carrier protein 1/2) probably play a role in oxidative protein folding [125]. PKD2 protein is a key signalling component in the cell wall synthesis [126]. Therefore, their expansion in organisms closely interacting with plants (Glomeromycota) or animals (Neocallimastigomycota) is not surprising.

Family 1.I.1 — the nuclear pore complex (NPC) family (formerly 1.A.75)—contains proteins with a variety of domain architectures, including proteins with domains from PKinase (CL0016) clan. As homologs of this family are present in outstanding numbers in Glomeromycotina, it is worth noting that these fungi show unusual cell organisation of their cells with multiple coexisting nuclei labelled as exhibiting polykaryosis [127].

The glycoside-pentoside-hexuronide (GPH):cation symporter family (2.A.2) catalyse the uptake of sugars and are present in all analysed taxa, with the greatest expansion in Basidiobolales and Mucoromycota. General alpha-glucoside permease sut1 from S. cerevisiae is responsible for the transport of maltose and sucrose into the cell [128]. This finding may be considered as a potential mechanism underlying the effective growth of Mucoromycota representatives on maltose and sucrose [50].

The mitochondrial carrier (MC) family (2.A.29) proteins transfer molecules across the membranes of the mitochondria. This family has a number of known fungal homologs and in our study is particularly abundant in Blastocladiomycota, Basidiobolales, and Mucoromycota. Among them are proteins that mediate the import of ADP into the mitochondrial matrix for ATP synthesis [129], dicarboxylic transporters catalysing the exchange of dicarboxylic acids such as malate and succinate for inorganic phosphate [130], proteins that transport FAD from the cytosol to the mitochondrial matrix [131].

The amino acid-polyamine-organocation (APC) superfamily (2.A.3) in our study is present in all studied fungi and has the greatest expansions in Basidiomycota and $\mathrm{Mu}$ coromycota. At least three APC subfamilies were experimentally characterized in fungi. The amino acid/choline transporter subfamily (2.A.3.4) includes transporters from fungi and Actinobacteria. Among them are $\gamma$-aminobutyric acid (GABA) permease and 7-keto-8aminopelargonic acid (KAPA) transporter, and vitamin B1 transporter. The L-type amino acid transporter (LAT) subfamily (2.A.3.8) includes fungal L-methionine transporter. Histidin, proline, arginine, glutamine, tryptophan, lysin, and leucine permeases are examples of proteins from subfamily 2.A.3.10 (the yeast amino acid transporter (YAT)) [113,132].

The cation diffusion facilitator (CDF) family (2.A.4) proteins transport heavy metals including cobalt, cadmium, iron, zinc and possibly nickel, copper and mercuric ions. There are known fungal mitochondrial, vacuolar and nuclear permeases [133]. Fungi are famous for their resistance to metal ions. In our study, CDF transporters are commonly present in Basidiobolales and Mucoromycota.

The endoplasmic reticular retrotranslocon (ER-RT or ERAD) family (3.A.16) are responsible for the translocation of misfolded protein from the lumen of the endoplasmic reticulum to cytoplasm, where they are degraded (e.g., Ssm4 from S. cerevisiae [134]). We noticed a huge expansion of ERAD translocons in Glomeromycotina.

The $\mathrm{H}^{+}$- or $\mathrm{Na}^{+}$-translocating F-type, V-type and A-type ATPase (F-ATPase) superfamily (3.A.2) was found in all studied taxa, but it is most abundant in plant-associated EDF. These enzymes catalyse the decomposition of ATP to ADP. They are necessary for cell metabolism - the export of toxins, wastes and solutes that may hinder cellular process. Ftype ATPases are found in eukaryotic mitochondria and chloroplasts, as well as in bacteria. 
V-type ATPases are found in the vacuoles of eukaryotes and in bacteria. A-type ATPases are found in archaea. [135].

The non-ABC multidrug exporter (N-MDE) family (9.A.1) was observed most commonly in Blastocladiomycota and Mucoromycota. The N-MDE family includes two fungal proteins with uncharacterized function: beta-chimaerin from Microsporum canis (C5FZG4) and Ncu02524 from Neurospora crassa (Q7SHT9).

\subsubsection{Uncharacterized Fungal Transporters}

The last group of transporters are proteins without characterized fungal homologs. For some of them, one can infer function on the basis of characterized proteins, e.g., from Metazoa or Bacteria. There are also proteins with neither known function in any branch of the tree of life nor with functions which have translation to fungi.

The mixed lineage kinase domain-like (MLKL) family (1.A.105) is characterized in humans. MLKL protein is a pseudokinase that plays a role in programmed cell death [136]. We found homologs of this family exclusively in Glomeromycotina. They possess a repetitive Sel1 domain (PF08238) with no clear function in fungi.

Family 1.A.33 (the cation channel-forming heat shock protein-70 (Hsp70) family) was noticed mostly in anaerobic chytrids and Glomeromycotina. Hsp70 representatives are molecular chaperones that are often associated with membranes. Hsp70 proteins are well known in humans. These proteins are implicated in a variety of cellular processes, including the protection of the proteome during stress, the folding and transport of newly synthesized proteins, and the activation of misfolded protein lysis [137].

Repeat-bearing protein families with ankyrin domains are expanded in Neocallimastigomycota. Such repeats were documented in diverse fungal proteins, including Yaprelated transcription factors [138] and NUC-2 protein [139]; however, studies on the role of these repeats in fungi are missing. Family 1.C.63 is known as the $\alpha$-latrotoxin (latrotoxin) family. The $\alpha$-latrotoxin family in TCDB includes solely Mediterranean black widow spider proteins [140] with Ank_2 (PF12796). The latter Ank_2 domain may play a role in protein folding [141]. The role of 1.C.63 in fungi is elusive. Additionally, the main ankyrin (ankyrin) family (8.A.28) does not include characterized fungal proteins. It is known that ankyrin repeats are involved in mediating protein-protein interactions [141].

The voltage-gated $\mathrm{K}+$ channel $\beta$-subunit $(\mathrm{Kv} \beta)$ family (8.A.5) has no characterized fungal homologs, but we found it in all studied taxa. It has the greatest expansion in Glomeromycotina. Rat protein Kcnab1 is a cytoplasmic subunit that promotes pore-forming by the channel-forming alpha-subunits [142].

The phosphotransferase system HPr (HPr) family (8.A.8) consists of bacterial proteins, all with the function of phosphoryl transfer protein. However, we found HPr homologs in several fungi, with a great number of copies in Glomeromycotina. ptsH protein from Escherichia coli is a major component of phosphoenolpyruvate-dependent sugar phosphotransferase system (sugar PTS). This carbohydrate active-transport system catalyses the phosphorylation of incoming sugar substrates concomitantly with their translocation across the cell membrane [143].

The guanylate cyclase (GC) family (8.A.85) controls many cellular processes from growth viability, and differentiation to contractility, secretion, and ion transport [144]. There are no described fungal guanylate cyclases, although in our analysis it turned out to be highly abundant in Glomeromycotina. Human and Bacteria characterized guanylate cyclases do not provide the grounds to infer about the function of this family in fungi.

The retromer assembly apparatus (RetromerAA) family (9.A.3) were detected in Neocallimastigomycota. The closest characterized RetromerAA homolog is the Snx27 human protein. It is involved in the trafficking pathway that promotes the recycling of internalized transmembrane proteins - proteins are delivered to the early endosome and recycled to the plasma membrane instead of being degraded in lysosomes [145]. It is an open question as to whether the molecular function was kept by all Opisthokonta descendants, including fungal homologs. 


\subsection{Protein Expansions and Ecology}

Expansions and losses observed in the sets of CaZymes, peptidases and transporters altogether reveal a landscape of adaptive combinations. One of the most illustrative examples comes from Neocallimastigomycota, anaerobic fungi which show a great abundance of CAZymes responsible for the degradation of organic plant matter such as xylan/pectin esterases, cellulases, and glucanases in numbers far greater compared with other plantassociated fungi. Neocallimastigomycota also show unique expansions of many peptidases: C110, G05, I04, M13, M20, S54, S08, C14, U69. The biological function of most of these peptidases and inhibitors still remains to be described, which prevents discussing their relevance to fungal ecology in more detail. In the case of transporters, anaerobic fungi show expansions of the ankyrin family, and the latrotoxin family (of yet unknown function in fungi). They share some expansion patterns with other symbionts such as arbuscular mycorrhizal fungi-both fungal groups have numerous channels involved in the stress response, such as Hsp70, VIC and TRP-CC (1.A.4). Glomeromycota additionally have more essential MLKL transporters and an ERAD transport system (associated with the degradation of misfolded protein) than other fungi. It has been shown before that mycorrhizal fungi possess several characteristic protein family contractions and losses involving plant-biomass-degrading enzymes [146]. However, in mycorrhizal systems the transporters have been described more thoroughly on the plant's side, leaving fungal counterparts uninvestigated [147].

Plant-associated Mucoromycota display a recursive expansion of the protein families involved in nutrition, drug and heavy metal resistance. However, not only nutrition-related CaZymes tend to be duplicated. Adaptasome CaZyme families are more often related to cell wall remodelling than to plant biomass degradation. This observation is in line with the role of the fungal cell wall as a key compartment crucial for the adaptation to a particular niche and stress response element $[55,148]$. Animal-associated fungi have a range of expansions related to pathogenicity and nutrition, providing a clear link between the host type and enzymes involved; peptidases for vertebrate parasites and chitinases for fungi living with invertebrates. Amphibian pathogens Batrachochytrium spp. have a much higher abundance of endopeptidase A01 and fungalysin than other fungi. Fungi which live with arthropods (as pathogen or commensal) have characteristic patterns of CAZymesthey have enzymes such as chitinases, specific kinds of glucanases, glucosidases and benzoquinone reductases. This is consistent with previous reports on protein family evolution in amphibian pathogens [149], dermatophytes [150] and entomopathogenic fungi [151].

\section{Conclusions}

The main goal of this study is to provide a rational explanation of how the presence of particular proteins shapes the adaptability of early-diverging fungi. Almost half of the protein families identified in our study as highly variable among EDF lineages have never been characterized in fungi and have no clear assignment of function. The observed distribution of several protein families with an unknown role in fungi underscores the ancestral inheritance shared with the remaining Opisthokonta lost in Dikarya. These protein families are not only present but also numerous and expressed in diverse isolates. These results point at an urgent need for experimental studies aimed at the functional characterization of adaptasome proteins. Particular homologs may display different regulatory mechanisms, substrate specificity and interacting partners in the biological context of individual strains or lineages.

We found that protein families, which have previously attracted attention, have dynamic evolutionary histories reflecting their adaptive potential towards new ecological challenges. Among others, ABC and MFS transporters, which enable resistance against multiple environmental threats $[152,153]$, are proteins involved in fungal cell wall biosynthesis such as chitin synthases (GT2) essential for interactions with other organisms and fungal defence [47]. Nutritional mode has a profound impact on the evolution of fungal genomes 
and the majority of differentially represented protein families in fungal proteomes are indeed associated with the digestion of nutrients (e.g., chitinases GH19 in fungi living with insects and loss of acetyl-xylan esterases CE2 and CE6 in endomycorrhizal Glomeromycota). The adaptasome encompasses a number of proteins involved in the modification of proteins which likely contribute to orchestrated protein regulation.

We also demonstrate a correlation between the adaptasome and ecological niches. This is particularly pronounced for anaerobic fungi and their outstanding repertoire of enzymes, enabling them to survive in atypical conditions. Neocallimastigomycota fungi may be classified as plant associated, and also as animal associated, but their family distribution patterns differs from patterns characteristic to both categories. Anaerobic fungi show an abundance of plant-degrading enzymes [154] and simultaneously unique expansions of peptidases and transporters. However, it is hard to determine which protein families are most relevant to the peculiar niche occupied by the anaerobic fungi since the precise biological function of many of these expanded protein families remains to be described. Neocallimastigomycota and other symbionts, such as arbuscular mycorrhizal fungi, are characterized by numerous channels involved in the stress response. One might speculate whether these channels have been co-opted to the symbiotic lifestyle and have a role in maintaining the relationship with the host.

Early-diverging fungi adopt a remarkable diversity of lifestyles and simultaneously are broadly sequenced, which makes them a good system to study genome-adaptability relationships. They share multiple common proteins with non-Dikarya opisthokonta, which raises many questions about their metabolism and ecology. The identified list of protein families provides a likely roadmap for the experimental phenotype screening of EDF and perhaps other fungal lineages. Some protein classes identified in this study were characterized exclusively in higher eukaryotes in specialized tissues, obviously not present in fungi. A more comprehensive understanding of the biology of EDF might provide invaluable insight into the key events in the evolution of life.

Supplementary Materials: The following supporting information can be downloaded at: https: / / www.mdpi.com/article/10.3390/jof8010067/s1, Supplementary Table S1: Table with numbers of homologs per adaptasome family in all studied non-Dikarya fungi. Supplementary Table S2: Table with information about the ecology of the analysed fungi derived from the literature. Supplementary Table S3: Accessions of all identified protein homologs. Supplementary Table S4: PMIDs of sources of information about all studied genomes. Supplementary Dataset DS1: File with phylogenetic (ML) trees of all studied protein families in non-Dikarya fungi in Newick format.

Author Contributions: Conceptualization, A.M. and M.O.; methodology, A.M. and M.O.; validation, A.M. and M.O.; formal analysis, A.M. and M.O.; investigation, A.M. and M.O.; data curation, M.O.; writing —original draft preparation, A.M. and M.O.; writing—review and editing, A.M. and M.O.; visualization, A.M. and M.O.; supervision, A.M.; project administration, A.M.; funding acquisition, A.M. All authors have read and agreed to the published version of the manuscript.

Funding: This work was supported by the Polish National Science Centre (grant 2017/25/B/NZ2/01880 to A.M.).

Institutional Review Board Statement: Not applicable.

Informed Consent Statement: Not applicable.

Data Availability Statement: The analyses are based on publicly available sequences. All identifiers of analysed proteins are listed in the Supplementary Materials. All trees built from those sequences are also listed in the Supplementary Materials.

Acknowledgments: We thank Marcin Grynberg, Julia Pawłowska and Kamil Steczkiewicz for their insight and comments about the manuscript. We would like to thank Blanka Sokołowska for her help with graphical abstract preparation.

Conflicts of Interest: The authors declare no conflict of interest. The funders had no role in the design of the study; in the collection, analyses, or interpretation of data; in the writing of the manuscript, or in the decision to publish the results. 


\section{References}

1. $\quad$ Li, Y.; Steenwyk, J.L.; Chang, Y.; Wang, Y.; James, T.Y.; Stajich, J.E.; Spatafora, J.W.; Groenewald, M.; Dunn, C.W.; Hittinger, C.T.; et al. A genome-scale phylogeny of the kingdom Fungi. Curr. Biol. 2021, 31, 1653-1665.e5. [CrossRef] [PubMed]

2. Hernández-Chávez, M.J.; Pérez-García, L.A.; Niño-Vega, G.A.; Mora-Montes, H.M. Fungal Strategies to Evade the Host Immune Recognition. J. Fungi 2017, 3, 51. [CrossRef]

3. Kamel, L.; Tang, N.; Malbreil, M.; San Clemente, H.; Le Marquer, M.; Roux, C.; Frei dit Frey, N. The Comparison of Expressed Candidate Secreted Proteins from Two Arbuscular Mycorrhizal Fungi Unravels Common and Specific Molecular Tools to Invade Different Host Plants. Front. Plant Sci. 2017, 8, 124. [CrossRef]

4. Hurdeal, V.G.; Gentekaki, E.; Hyde, K.D.; Jeewon, R. Where are the basal fungi? Current status on diversity, ecology, evolution, and taxonomy. Biologia 2021, 76, 421-440. [CrossRef]

5. Kiss, E.; Hegedüs, B.; Virágh, M.; Varga, T.; Merényi, Z.; Kószó, T.; Bálint, B.; Prasanna, A.N.; Krizsán, K.; Kocsubé, S.; et al. Comparative genomics reveals the origin of fungal hyphae and multicellularity. Nat. Commun. 2019, 10, 4080. [CrossRef]

6. Põlme, S.; Abarenkov, K.; Nilsson, R.H.; Lindahl, B.D.; Clemmensen, K.E.; Kauserud, H.; Nguyen, N.; Kjøller, R.; Bates, S.T.; Baldrian, P.; et al. FungalTraits: A user-friendly traits database of fungi and fungus-like stramenopiles. Fungal Divers. 2020, 105, 1-16. [CrossRef]

7. Demuth, J.P.; Hahn, M.W. The life and death of gene families. Bioessays 2009, 31, 29-39. [CrossRef]

8. Albertin, W.; Marullo, P. Polyploidy in fungi: Evolution after whole-genome duplication. Proc. Biol. Sci. 2012, 279, 2497-2509. [CrossRef]

9. Spanu, P.D.; Abbott, J.C.; Amselem, J.; Burgis, T.A.; Soanes, D.M.; Stüber, K.; van Themaat, E.V.L.; Brown, J.K.; Butcher, S.A.; Gurr, S.J.; et al. Genome expansion and gene loss in powdery mildew fungi reveal tradeoffs in extreme parasitism. Science 2010, 330, 1543-1546. [CrossRef] [PubMed]

10. Zhang, W.; Zhang, X.; Li, K.; Wang, C.; Cai, L.; Zhuang, W.; Xiang, M.; Liu, X. Introgression and gene family contraction drive the evolution of lifestyle and host shifts of hypocrealean fungi. Mycology 2018, 9, 176-188. [CrossRef] [PubMed]

11. Tunlid, A.; Talbot, N.J. Genomics of parasitic and symbiotic fungi. Curr. Opin. Microbiol. 2002, 5, 513-519. [CrossRef]

12. Hage, H.; Miyauchi, S.; Virágh, M.; Drula, E.; Min, B.; Chaduli, D.; Navarro, D.; Favel, A.; Norest, M.; Lesage-Meessen, L.; et al. Gene family expansions and transcriptome signatures uncover fungal adaptations to wood decay. Environ. Microbiol. 2021, 23, 5716-5732. [CrossRef]

13. Andreis, F.C.; Schrank, A.; Thompson, C.E. Molecular evolution of Pr1 proteases depicts ongoing diversification in Metarhizium spp. Mol. Genet. Genom. 2019, 294, 901-917. [CrossRef] [PubMed]

14. Sommer, B.; Overy, D.P.; Kerr, R.G. Identification and characterization of lipases from Malassezia restricta, a causative agent of dandruff. FEMS Yeast Res. 2015, 15, fov078. [CrossRef] [PubMed]

15. Rawlings, N.D.; Waller, M.; Barrett, A.J.; Bateman, A. MEROPS: The database of proteolytic enzymes, their substrates and inhibitors. Nucleic Acids Res. 2014, 42, D503-D509. [CrossRef]

16. Lombard, V.; Ramulu, H.G.; Drula, E.; Coutinho, P.M.; Henrissat, B. The carbohydrate-active enzymes database (CAZy) in 2013 Nucleic Acids Res. 2014, 42, D490-D495. [CrossRef] [PubMed]

17. Saier, M.H., Jr.; Reddy, V.S.; Moreno-Hagelsieb, G.; Hendargo, K.J.; Zhang, Y.; Iddamsetty, V.; Lam, K.J.K.; Tian, N.; Russum, S.; Wang, J.; et al. The Transporter Classification Database (TCDB): 2021 update. Nucleic Acids Res. 2021, 49, D461-D467. [CrossRef]

18. Seppey, M.; Manni, M.; Zdobnov, E.M. BUSCO: Assessing Genome Assembly and Annotation Completeness. Methods Mol. Biol. 2019, 1962, 227-245.

19. Ellinghaus, D.; Kurtz, S.; Willhoeft, U. LTRharvest, an efficient and flexible software for de novo detection of LTR retrotransposons. BMC Bioinform. 2008, 9, 18. [CrossRef]

20. Altschul, S.F.; Gish, W.; Miller, W.; Myers, E.W.; Lipman, D.J. Basic local alignment search tool. J. Mol. Biol. 1990, 215, 403-410. [CrossRef]

21. Potter, S.C.; Luciani, A.; Eddy, S.R.; Park, Y.; Lopez, R.; Finn, R.D. HMMER web server: 2018 update. Nucleic Acids Res. 2018, 46, W200-W204. [CrossRef] [PubMed]

22. Yamada, K.D.; Tomii, K.; Katoh, K. Application of the MAFFT sequence alignment program to large data-Reexamination of the usefulness of chained guide trees. Bioinformatics 2016, 32, 3246-3251. [CrossRef]

23. Frickey, T.; Lupas, A. CLANS: A Java application for visualizing protein families based on pairwise similarity. Bioinformatics 2004, 20, 3702-3704. [CrossRef]

24. Capella-Gutiérrez, S.; Silla-Martínez, J.M.; Gabaldón, T. trimAl: A tool for automated alignment trimming in large-scale phylogenetic analyses. Bioinformatics 2009, 25, 1972-1973. [CrossRef] [PubMed]

25. Minh, B.Q.; Schmidt, H.A.; Chernomor, O.; Schrempf, D.; Woodhams, M.D.; Von Haeseler, A.; Lanfear, R. IQ-TREE 2: New models and efficient methods for phylogenetic inference in the genomic era. Mol. Biol. Evol. 2020, 37, 1530-1534. [CrossRef]

26. Finn, R.D.; Coggill, P.; Eberhardt, R.Y.; Eddy, S.R.; Mistry, J.; Mitchell, A.L.; Potter, S.C.; Punta, M.; Qureshi, M.; Sangrador-Vegas, A.; et al. The Pfam protein families database: Towards a more sustainable future. Nucleic Acids Res. 2016, 44, D279-D285. [CrossRef] [PubMed]

27. Horton, P.; Park, K.-J.; Obayashi, T.; Fujita, N.; Harada, H.; Adams-Collier, C.J.; Nakai, K. WoLF PSORT: Protein localization predictor. Nucleic Acids Res. 2007, 35, W585-W587. [CrossRef] 
28. Armenteros, J.J.A.; Tsirigos, K.D.; Sønderby, C.K.; Petersen, T.N.; Winther, O.; Brunak, S.; Von Heijne, G.; Nielsen, H. SignalP 5.0 improves signal peptide predictions using deep neural networks. Nat. Biotechnol. 2019, 37, 420-423. [CrossRef]

29. Letunic, I.; Bork, P. Interactive Tree of Life (iTOL) v5: An online tool for phylogenetic tree display and annotation. Nucleic Acids Res. 2021, 49, W293-W296. [CrossRef] [PubMed]

30. Close, D.W.; D'Angelo, S.; Bradbury, A.R.M. A new family of $\beta$-helix proteins with similarities to the polysaccharide lyases. Acta Crystallogr. D Biol. Crystallogr. 2014, 70, 2583-2592. [CrossRef]

31. Gryganskyi, A.P.; Golan, J.; Dolatabadi, S.; Mondo, S.; Robb, S.; Idnurm, A.; Muszewska, A.; Steczkiewicz, K.; Masonjones, S.; Liao, H.-L.; et al. Phylogenetic and Phylogenomic Definition of Species. G3 2018, 8, 2007-2018. [CrossRef]

32. Kuuskeri, J.; Häkkinen, M.; Laine, P.; Smolander, O.P.; Tamene, F.; Miettinen, S.; Nousiainen, P.; Kemell, M.; Auvinen, P.; Lundell, T. Time-scale dynamics of proteome and transcriptome of the white-rot fungus Phlebia radiata: Growth on spruce wood and decay effect on lignocellulose. Biotechnol. Biofuels 2016, 9, 192. [CrossRef]

33. Jensen, K.A., Jr.; Ryan, Z.C.; Vanden Wymelenberg, A.; Cullen, D.; Hammel, K.E. An NADH: Quinone oxidoreductase active during biodegradation by the brown-rot basidiomycete Gloeophyllum trabeum. Appl. Environ. Microbiol. 2002, 68, $2699-2703$. [CrossRef]

34. Pedrini, N.; Ortiz-Urquiza, A.; Huarte-Bonnet, C.; Fan, Y.; Juárez, M.P.; Keyhani, N.O. Tenebrionid secretions and a fungal benzoquinone oxidoreductase form competing components of an arms race between a host and pathogen. Proc. Natl. Acad. Sci. USA 2015, 112, E3651-E3660. [CrossRef] [PubMed]

35. Rühl, M.; Majcherczyk, A.; Kües, U. Lcc1 and Lcc5 are the main laccases secreted in liquid cultures of Coprinopsis cinerea strains. Antonie Van Leeuwenhoek 2013, 103, 1029-1039. [CrossRef]

36. Kameshwar, A.K.S.; Qin, W. Systematic review of publicly available non-Dikarya fungal proteomes for understanding their plant biomass-degrading and bioremediation potentials. Bioresour. Bioprocess. 2019, 6, 30. [CrossRef]

37. Prakash, O.; Mahabare, K.; Yadav, K.K.; Sharma, R. Fungi from extreme environments: A potential source of laccases group of extremozymes. In Fungi in Extreme Environments: Ecological Role and Biotechnological Significance; Springer International Publishing: Cham, Switzerland, 2019; pp. 441-462.

38. Momeni, M.H.; Fredslund, F.; Bissaro, B.; Raji, O.; Vuong, T.V.; Meier, S.; Nielsen, T.S.; Lombard, V.; Guigliarelli, B.; Biaso, F.; et al. Discovery of fungal oligosaccharide-oxidising flavo-enzymes with previously unknown substrates, redox-activity profiles and interplay with LPMOs. Nat Commun. 2021, 12, 2132. [CrossRef] [PubMed]

39. Andlar, M.; Rezić, T.; Marđetko, N.; Kracher, D.; Ludwig, R.; Šantek, B. Lignocellulose degradation: An overview of fungi and fungal enzymes involved in lignocellulose degradation. Eng. Life Sci. 2018, 18, 768-778. [CrossRef] [PubMed]

40. Nagy, L.G.; Riley, R.; Tritt, A.; Adam, C.; Daum, C.; Floudas, D.; Sun, H.; Yadav, J.S.; Pangilinan, J.; Larsson, K.H.; et al. Comparative Genomics of Early-Diverging Mushroom-Forming Fungi Provides Insights into the Origins of Lignocellulose Decay Capabilities. Mol. Biol. Evol. 2016, 33, 959-970. [CrossRef]

41. Hess, M.; Paul, S.S.; Puniya, A.K.; Van Der Giezen, M.; Shaw, C.; Edwards, J.E.; Fliegerová, K. Anaerobic Fungi: Past, Present, and Future. Front. Microbiol. 2020, 11, 584893. [CrossRef]

42. Murphy, C.L.; Youssef, N.H.; Hanafy, R.; Couger, M.B.; Stajich, J.E.; Wang, Y.; Baker, K.; Dagar, S.S.; Griffith, G.W.; Farag, I.F.; et al. Horizontal Gene Transfer as an Indispensable Driver for Evolution of Neocallimastigomycota into a Distinct Gut-Dwelling Fungal Lineage. Appl. Environ. Microbiol. 2019, 85, e00988-19. [CrossRef]

43. Muszewska, A.; Piłsyk, S.; Perlińska-Lenart, U.; Kruszewska, J.S. Diversity of Cell Wall Related Proteins in Human Pathogenic Fungi. J. Fungi 2017, 4, 6. [CrossRef] [PubMed]

44. Bellincampi, D.; Cervone, F.; Lionetti, V. Plant cell wall dynamics and wall-related susceptibility in plant-pathogen interactions. Front. Plant Sci. 2014, 5, 228. [CrossRef]

45. Andrés, E.; Albesa-Jové, D.; Biarnés, X.; Moerschbacher, B.M.; Guerin, M.E.; Planas, A. Structural basis of chitin oligosaccharide deacetylation. Angew. Chem. Weinheim. Bergstr. Ger. 2014, 126, 7002-7007. [CrossRef]

46. Lastovetsky, O.A.; Krasnovsky, L.D.; Qin, X.; Gaspar, M.L.; Gryganskyi, A.P.; Huntemann, M.; Clum, A.; Pillay, M.; Palaniappan, K.; Varghese, N.; et al. Molecular Dialogues between Early Divergent Fungi and Bacteria in an Antagonism versus a Mutualism. mBio 2020, 11, e02088-20. [CrossRef]

47. Mélida, H.; Sain, D.; Stajich, J.E.; Bulone, V. Deciphering the uniqueness of Mucoromycotina cell walls by combining biochemical and phylogenomic approaches. Environ. Microbiol. 2015, 17, 1649-1662. [CrossRef] [PubMed]

48. van den Brink, J.; de Vries, R.P. Fungal enzyme sets for plant polysaccharide degradation. Appl. Microbiol. Biotechnol. 2011, 91, 1477-1492. [CrossRef] [PubMed]

49. Zhao, Z.; Liu, H.; Wang, C.; Xu, J.-R. Comparative analysis of fungal genomes reveals different plant cell wall degrading capacity in fungi. BMC Genom. 2013, 14, 274. [CrossRef]

50. Pawłowska, J.; Okrasińska, A.; Kisło, K.; Aleksandrzak-Piekarczyk, T.; Szatraj, K.; Dolatabadi, S.; Muszewska, A. Carbon assimilation profiles of mucoralean fungi show their metabolic versatility. Sci. Rep. 2019, 9, 11864. [CrossRef]

51. Mewis, K.; Lenfant, N.; Lombard, V.; Henrissat, B. Dividing the Large Glycoside Hydrolase Family 43 into Subfamilies: A Motivation for Detailed Enzyme Characterization. Appl. Environ. Microbiol. 2016, 82, 1686-1692. [CrossRef]

52. Moussa, S.H.; Kuznetsov, V.; Tran, T.A.T.; Sacchettini, J.C.; Young, R. Protein determinants of phage T4 lysis inhibition. Protein Sci. 2012, 21, 571-582. [CrossRef] 
53. Briard, B.; Muszkieta, L.; Latgé, J.-P.; Fontaine, T. Galactosaminogalactan of Aspergillus fumigatus, a bioactive fungal polymer. Mycologia 2016, 108, 572-580. [CrossRef]

54. Balestrini, R.; Bonfante, P. Cell wall remodeling in mycorrhizal symbiosis: A way towards biotrophism. Front. Plant Sci. 2014, 5 , 237. [CrossRef]

55. Hopke, A.; Brown, A.J.P.; Hall, R.A.; Wheeler, R.T. Dynamic Fungal Cell Wall Architecture in Stress Adaptation and Immune Evasion. Trends Microbiol. 2018, 26, 284-295. [CrossRef] [PubMed]

56. Bamford, N.C.; Le Mauff, F.; Subramanian, A.S.; Yip, P.; Millán, C.; Zhang, Y.; Zacharias, C.; Forman, A.; Nitz, M.; Codée, J.D.; et al. Ega3 from the fungal pathogen is an endo- $\alpha-1,4$-galactosaminidase that disrupts microbial biofilms. J. Biol. Chem. 2019, 294, 13833-13849. [CrossRef]

57. Spatafora, J.W.; Chang, Y.; Benny, G.L.; Lazarus, K.; Smith, M.E.; Berbee, M.L.; Bonito, G.; Corradi, N.; Grigoriev, I.; Gryganskyi, A.; et al. A phylum-level phylogenetic classification of zygomycete fungi based on genome-scale data. Mycologia 2016, 108, 1028-1046. [CrossRef]

58. Han, B.; Zhou, K.; Li, Z.; Sun, B.; Ni, Q.; Meng, X.; Pan, G.; Li, C.; Long, M.; Li, T.; et al. Characterization of the First Fungal Glycosyl Hydrolase Family 19 Chitinase (NbchiA) from Nosema bombycis (Nb). J. Eukaryot. Microbiol. 2016, 63, 37-45. [CrossRef] [PubMed]

59. Yano, S.; Kanno, H.; Tsuhako, H.; Ogasawara, S.; Suyotha, W.; Konno, H.; Makabe, K.; Uechi, K.; Taira, T. Cloning, expression, and characterization of a GH 19-type chitinase with antifungal activity from Lysobacter sp. MK9-1. J. Biosci. Bioeng. 2021, 131, 348-355. [CrossRef] [PubMed]

60. Norice, C.T.; Smith, F.J., Jr.; Solis, N.; Filler, S.G.; Mitchell, A.P. Requirement for Candida albicans Sun41 in biofilm formation and virulence. Eukaryot. Cell 2007, 6, 2046-2055. [CrossRef]

61. Schwerdt, J.; Qiu, H.; Shirley, N.; Little, A.; Bulone, V. Phylogenomic Analyses of Nucleotide-Sugar Biosynthetic and Interconverting Enzymes Illuminate Cell Wall Composition in Fungi. mBio 2021, 12, e03540-20. [CrossRef]

62. Corfield, A.P.; Berry, M. Glycan variation and evolution in the eukaryotes. Trends Biochem. Sci. 2015, 40, 351-359. [CrossRef]

63. Brockington, M.; Torelli, S.; Prandini, P.; Boito, C.; Dolatshad, N.F.; Longman, C.; Brown, S.; Muntoni, F. Localization and functional analysis of the LARGE family of glycosyltransferases: Significance for muscular dystrophy. Hum. Mol. Genet. 2005, 14, 657-665. [CrossRef] [PubMed]

64. Valdivieso, M.H.; Henar Valdivieso, M.; Durán, A.; Roncero, C. Chitin synthases in yeast and fungi. Chitin Chitinases 1999, 87, 55-69. [CrossRef]

65. Ikeda, Y.; Ohashi, T.; Tanaka, N.; Takegawa, K. Identification and characterization of a gene required for alpha1,2-mannose extension in the O-linked glycan synthesis pathway in Schizosaccharomyces pombe. FEMS Yeast Res. 2009, 9, 115-125. [CrossRef]

66. Sommer, U.; Liu, H.; Doering, T.L. An alpha-1,3-mannosyltransferase of Cryptococcus neoformans. J. Biol. Chem. 2003, 278, 47724-47730. [CrossRef]

67. Yip, C.L.; Welch, S.K.; Klebl, F.; Gilbert, T.; Seidel, P.; Grant, F.J.; O'Hara, P.J.; MacKay, V.L. Cloning and analysis of the Saccharomyces cerevisiae MNN9 and MNN1 genes required for complex glycosylation of secreted proteins. Proc. Natl. Acad. Sci. USA 1994, 91, 2723-2727. [CrossRef]

68. Holdener, B.C.; Haltiwanger, R.S. Protein O-fucosylation: Structure and function. Curr. Opin. Struct. Biol. 2019, 56, 78-86. [CrossRef] [PubMed]

69. Muszewska, A.; Okrasińska, A.; Steczkiewicz, K.; Drgas, O.; Orłowska, M.; Perlińska-Lenart, U.; Aleksandrzak-Piekarczyk, T.; Szatraj, K.; Zielenkiewicz, U.; Piłsyk, S.; et al. Metabolic Potential, Ecology and Presence of Associated Bacteria Is Reflected in Genomic Diversity of Mucoromycotina. Front. Microbiol. 2021, 12, 636986. [CrossRef] [PubMed]

70. Coutinho, P.M.; Andersen, M.R.; Kolenova, K.; Vankuyk, P.A.; Benoit, I.; Gruben, B.S.; Trejo-Aguilar, B.; Visser, H.; Van Solingen, P.; Pakula, T. Post-genomic insights into the plant polysaccharide degradation potential of Aspergillus nidulans and comparison to Aspergillus niger and Aspergillus oryzae. Fungal Genet. Biol. 2009, 46 (Suppl. 1), S161-S169. [CrossRef] [PubMed]

71. Kohler, A.; Kuo, A.; Nagy, L.G.; Morin, E.; Barry, K.W.; Buscot, F.; Canbäck, B.; Choi, C.; Cichocki, N.; Clum, A.; et al. Convergent losses of decay mechanisms and rapid turnover of symbiosis genes in mycorrhizal mutualists. Nat. Genet. 2015, 47, 410-415. [CrossRef]

72. McDonald, C.A.; Ellison, A.R.; Toledo, L.F.; James, T.Y.; Zamudio, K.R. Gene expression varies within and between enzootic and epizootic lineages of Batrachochytrium dendrobatidis (Bd) in the Americas. Fungal Biol. 2020, 124, 34-43. [CrossRef]

73. Fisher, M.C.; Pasmans, F.; Martel, A. Virulence and Pathogenicity of Chytrid Fungi Causing Amphibian Extinctions. Annu. Rev. Microbiol. 2021, 75, 673-693. [CrossRef] [PubMed]

74. Pellegrin, C.; Morin, E.; Martin, F.M.; Veneault-Fourrey, C. Comparative Analysis of Secretomes from Ectomycorrhizal Fungi with an Emphasis on Small-Secreted Proteins. Front. Microbiol. 2015, 6, 1278. [CrossRef] [PubMed]

75. Llorens, C.; Futami, R.; Renaud, G.; Moya, A. Bioinformatic flowchart and database to investigate the origins and diversity of clan AA peptidases. Biol. Direct 2009, 4, 3. [CrossRef] [PubMed]

76. Muszewska, A.; Hoffman-Sommer, M.; Grynberg, M. LTR Retrotransposons in Fungi. PLoS ONE 2011, 6, e29425. [CrossRef] [PubMed]

77. Muszewska, A.; Steczkiewicz, K.; Stepniewska-Dziubinska, M.; Ginalski, K. Transposable elements contribute to fungal genes and impact fungal lifestyle. Sci. Rep. 2019, 9, 4307. [CrossRef] 
78. Gonçalves, A.P.; Heller, J.; Daskalov, A.; Videira, A.; Glass, N.L. Regulated Forms of Cell Death in Fungi. Front. Microbiol. 2017, 8, 1837. [CrossRef]

79. Kamlangdee, N. Identifying Target Proteins of the CreB Deubiquitination Enzyme in the Fungus Aspergillus Nidulans. Ph.D. Thesis, University of Adelaide, Adelaide, Australia, 2007.

80. Katz, M.E.; Bernardo, S.M.; Cheetham, B.F. The interaction of induction, repression and starvation in the regulation of extracellular proteases in Aspergillus nidulans: Evidence for a role for CreA in the response to carbon starvation. Curr. Genet. 2008, 54, 47-55. [CrossRef]

81. Denton, J.A.; Kelly, J.M. Disruption of Trichoderma reesei cre2, encoding an ubiquitin C-terminal hydrolase, results in increased cellulase activity. BMC Biotechnol. 2011, 11, 103. [CrossRef]

82. Mateus, I.D.; Rojas, E.C.; Savary, R.; Dupuis, C.; Masclaux, F.G.; Aletti, C.; Sanders, I.R. Coexistence of genetically different Rhizophagus irregularis isolates induces genes involved in a putative fungal mating response. ISME J. 2020, 14, $2381-2394$. [CrossRef]

83. Green, C.M.; Novikova, O.; Belfort, M. The dynamic intein landscape of eukaryotes. Mob. DNA 2018, 9, 4. [CrossRef] [PubMed]

84. Xin, F.; Wang, S.; Song, L.; Liang, Q.; Qi, Q. Molecular identification and characterization of peptide: N-glycanase from Schizosaccharomyces pombe. Biochem. Biophys. Res. Commun. 2008, 368, 907-912. [CrossRef]

85. Seppälä, S.; Lankiewicz, T.S.; Saxena, M.; Henske, J.K.; Salamov, A.A.; Grigoriev, I.V.; O’Malley, M.A. Genomic and proteomic biases inform metabolic engineering strategies for anaerobic fungi. Metab. Eng. Commun. 2020, 10, e00107.

86. Pei, J.; Grishin, N.V. Type II CAAX prenyl endopeptidases belong to a novel superfamily of putative membrane-bound metalloproteases. Trends Biochem. Sci. 2001, 26, 275-277. [CrossRef]

87. Steenbakkers, P.J.; Irving, J.A.; Harhangi, H.R.; Swinkels, W.J.; Akhmanova, A.; Dijkerman, R.; Jetten, M.S.; van der Drift, C.; Whisstock, J.C.; Camp, H.J.O.D. A serpin in the cellulosome of the anaerobic fungus Piromyces sp. strain E2. Mycol. Res. 2008, 112, 999-1006. [CrossRef]

88. Janer, C.; Arigoni, F.; Lee, B.H.; Peláez, C.; Requena, T. Enzymatic ability of Bifidobacterium animalis subsp. lactis to hydrolyze milk proteins: Identification and characterization of endopeptidase O. Appl. Environ. Microbiol. 2005, 71, 8460-8465. [CrossRef]

89. Lindner, H.A.; Lunin, V.V.; Alary, A.; Hecker, R.; Cygler, M.; Ménard, R. Essential roles of zinc ligation and enzyme dimerization for catalysis in the aminoacylase-1/M20 family. J. Biol. Chem. 2003, 278, 44496-44504. [CrossRef]

90. Zuo, S.; Guo, Q.; Ling, C.; Chang, Y.H. Evidence that two zinc fingers in the methionine aminopeptidase from Saccharomyces cerevisiae are important for normal growth. Mol. Gen. Genet. 1995, 246, 247-253. [CrossRef]

91. Cottrell, G.S.; Hooper, N.M.; Turner, A.J. Cloning, expression, and characterization of human cytosolic aminopeptidase P: A single manganese(II)-dependent enzyme. Biochemistry 2000, 39, 15121-15128. [CrossRef]

92. Knedlík, T.; Vorlová, B.; Navrátil, V.; Tykvart, J.; Sedlák, F.; Vaculín, Š.; Franěk, M.; Šácha, P.; Konvalinka, J. Mouse glutamate carboxypeptidase II (GCPII) has a similar enzyme activity and inhibition profile but a different tissue distribution to human GCPII. FEBS Open Bio 2017, 7, 1362-1378. [CrossRef]

93. Cheng, Y.; Zak, O.; Aisen, P.; Harrison, S.C.; Walz, T. Structure of the human transferrin receptor-transferrin complex. Cell 2004, 116, 565-576. [CrossRef]

94. Rutherford, J.C. The emerging role of urease as a general microbial virulence factor. PLoS Pathog. 2014, 10, e1004062. [CrossRef]

95. Hu, P.; Ding, H.; Shen, L.; He, G.-J.; Liu, H.; Tian, X.; Tao, C.; Bai, X.; Liang, J.; Jin, C.; et al. A unique cell wall synthetic response evoked by glucosamine determines pathogenicity-associated fungal cellular differentiation. PLoS Genet. 2021, 17, e1009817. [CrossRef] [PubMed]

96. Dubovenko, A.G.; Dunaevsky, Y.E.; Belozersky, M.A.; Oppert, B.; Lord, J.C.; Elpidina, E.N. Trypsin-like proteins of the fungi as possible markers of pathogenicity. Fungal Biol. 2010, 114, 151-159. [CrossRef]

97. Leger, R.J.S.; Joshi, L.; Roberts, D.W. Adaptation of proteases and carbohydrates of saprophytic, phytopathogenic and entomopathogenic fungi to the requirements of their ecological niches. Microbiology 1997, 143 Pt 6, 1983-1992. [CrossRef]

98. Muszewska, A.; Stepniewska-Dziubinska, M.M.; Steczkiewicz, K.; Pawlowska, J.; Dziedzic, A.; Ginalski, K. Fungal lifestyle reflected in serine protease repertoire. Sci. Rep. 2017, 7, 9147. [CrossRef]

99. Li, Q.; Zhang, N.; Zhang, L.; Ma, H. Differential evolution of members of the rhomboid gene family with conservative and divergent patterns. New Phytol. 2015, 206, 368-380. [CrossRef] [PubMed]

100. Marger, M.D.; Saier, M.H. A major superfamily of transmembrane facilitators that catalyse uniport, symport and antiport. Trends Biochem. Sci. 1993, 18, 13-20. [CrossRef]

101. Celenza, J.L.; Marshall-Carlson, L.; Carlson, M. The yeast SNF3 gene encodes a glucose transporter homologous to the mammalian protein. Proc. Natl. Acad. Sci. USA 1988, 85, 2130-2134. [CrossRef]

102. Heiland, S.; Radovanovic, N.; Höfer, M.; Winderickx, J.; Lichtenberg, H. Multiple hexose transporters of Schizosaccharomyces pombe. J. Bacteriol. 2000, 182, 2153-2162. [CrossRef] [PubMed]

103. Chang, Y.D.; Dickson, R.C. Primary structure of the lactose permease gene from the yeast Kluyveromyces lactis. Presence of an unusual transcript structure. J. Biol. Chem. 1988, 263, 16696-16703. [CrossRef]

104. Yao, B.; Sollitti, P.; Marmur, J. Primary structure of the maltose-permease-encoding gene of Saccharomyces carlsbergensis. Gene 1989, 79, 189-197. [CrossRef]

105. Mannhaupt, G. What's in the genome of a filamentous fungus? Analysis of the Neurospora genome sequence. Nucleic Acids Res. 2003, 31, 1944-1954. [CrossRef] [PubMed] 
106. Jones, P.M.; George, A.M. The ABC transporter structure and mechanism: Perspectives on recent research. Cell. Mol. Life Sci. 2004, 61, 682-699. [CrossRef] [PubMed]

107. Fedorova, N.D.; Khaldi, N.; Joardar, V.S.; Maiti, R.; Amedeo, P.; Anderson, M.J.; Crabtree, J.; Silva, J.C.; Badger, J.H.; Albarraq, A.; et al. Genomic islands in the pathogenic filamentous fungus Aspergillus fumigatus. PLoS Genet. 2008, 4, e1000046. [CrossRef]

108. Ghaemmaghami, S.; Huh, W.-K.; Bower, K.; Howson, R.W.; Belle, A.; Dephoure, N.; O'Shea, E.K.; Weissman, J.S. Global analysis of protein expression in yeast. Nature 2003, 425, 737-741. [CrossRef]

109. Bowman, S.; Churcher, C.; Badcock, K.; Brown, D.; Chillingworth, T.; Connor, R.; Dedman, K.; Devlin, K.; Gentles, S.; Hamlin, N.; et al. The nucleotide sequence of Saccharomyces cerevisiae chromosome XIII. Nature 1997, 387, 90-93. [CrossRef] [PubMed]

110. Roy, S.K.; Chiba, Y.; Takeuchi, M.; Jigami, Y. Characterization of Yeast Yea4p, a uridine diphosphate-N-acetylglucosamine transporter localized in the endoplasmic reticulum and required for chitin synthesis. J. Biol. Chem. 2000, 275, 13580-13587. [CrossRef]

111. Nakanishi, H.; Nakayama, K.-I.; Yokota, A.; Tachikawa, H.; Takahashi, N.; Jigami, Y. Hut1 proteins identified inSaccharomyces cerevisiae andSchizosaccharomyces pombe are functional homologues involved in the protein-folding process at the endoplasmic reticulum. Yeast 2001, 18, 543-554. [CrossRef]

112. Nishikawa, A.; Poster, J.B.; Jigami, Y.; Dean, N. Molecular and phenotypic analysis of CaVRG4, encoding an essential Golgi apparatus GDP-mannose transporter. J. Bacteriol. 2002, 184, 29-42. [CrossRef]

113. Wood, V.; Gwilliam, R.; Rajandream, M.-A.; Lyne, M.; Lyne, R.; Stewart, A.; Sgouros, J.; Peat, N.; Hayles, J.; Baker, S.; et al. The genome sequence of Schizosaccharomyces pombe. Nature 2002, 415, 871-880. [CrossRef]

114. Jacq, C.; Alt-Mörbe, J.; Andre, B.; Arnold, W.; Bahr, A.; Ballesta, J.P.G.; Bargues, M.; Baron, L.; Becker, A.; Biteau, N.; et al. The nucleotide sequence of Saccharomyces cerevisiae chromosome IV. Nature 1997, 387, 75-78. [CrossRef] [PubMed]

115. Goytain, A.; Hines, R.M.; El-Husseini, A.; Quamme, G.A. NIPA1(SPG6), the basis for autosomal dominant form of hereditary spastic paraplegia, encodes a functional $\mathrm{Mg}^{2+}$ transporter. J. Biol. Chem. 2007, 282, 8060-8068. [CrossRef] [PubMed]

116. Uemura, S.; Kihara, A.; Inokuchi, J.-I.; Igarashi, Y. Csg1p and newly identified Csh1p function in mannosylinositol phosphorylceramide synthesis by interacting with Csg2p. J. Biol. Chem. 2003, 278, 45049-45055. [CrossRef]

117. Greenwald, J.; Buhtz, C.; Ritter, C.; Kwiatkowski, W.; Choe, S.; Maddelein, M.-L.; Ness, F.; Cescau, S.; Soragni, A.; Leitz, D.; et al. The mechanism of prion inhibition by HET-S. Mol. Cell. 2010, 38, 889-899. [CrossRef]

118. Bankaitis, V.A.; Johnson, L.M.; Emr, S.D. Isolation of yeast mutants defective in protein targeting to the vacuole. Proc. Natl. Acad. Sci. USA 1986, 83, 9075-9079. [CrossRef] [PubMed]

119. Oliveira, D.L.; Rizzo, J.; Joffe, L.S.; Godinho, R.M.C.; Rodrigues, M.L. Where do they come from and where do they go: Candidates for regulating extracellular vesicle formation in fungi. Int. J. Mol. Sci. 2013, 14, 9581-9603. [CrossRef]

120. Zhu, X.-M.; Li, L.; Wu, M.; Liang, S.; Shi, H.-B.; Liu, X.-H.; Lin, F.-C. Current opinions on autophagy in pathogenicity of fungi. Virulence 2019, 10, 481-489. [CrossRef]

121. Trip, H.; Evers, M.E.; Driessen, A.J.M. PcMtr, an aromatic and neutral aliphatic amino acid permease of Penicillium chrysogenum. Biochim. Biophys. Acta 2004, 1667, 167-173. [CrossRef]

122. Lewis, A.; McCrossan, Z.A.; Manville, R.W.; Popa, M.O.; Cuello, L.G.; Goldstein, S.A.N. TOK channels use the two gates in classical K channels to achieve outward rectification. FASEB J. 2020, 34, 8902-8919. [CrossRef]

123. Paidhungat, M.; Garrett, S. A homolog of mammalian, voltage-gated calcium channels mediates yeast pheromone-stimulated $\mathrm{Ca}^{2+}$ uptake and exacerbates the cdc1(Ts) growth defect. Mol. Cell. Biol. 1997, 17, 6339-6347. [CrossRef]

124. Denis, V.; Cyert, M.S. Internal $\mathrm{Ca}^{2+}$ release in yeast is triggered by hypertonic shock and mediated by a TRP channel homologue. J. Cell Biol. 2002, 156, 29-34. [CrossRef] [PubMed]

125. Protchenko, O.; Rodriguez-Suarez, R.; Androphy, R.; Bussey, H.; Philpott, C.C. A screen for genes of heme uptake identifies the FLC family required for import of FAD into the endoplasmic reticulum. J. Biol. Chem. 2006, 281, 21445-21457. [CrossRef]

126. Palmer, C.P.; Aydar, E.; Djamgoz, M.B.A. A microbial TRP-like polycystic-kidney-disease-related ion channel gene. Biochem. J. 2005, 387, 211-219. [CrossRef]

127. Pawlowska, T.E.; Taylor, J.W. Organization of genetic variation in individuals of arbuscular mycorrhizal fungi. Nature 2004, 427, 733-737. [CrossRef] [PubMed]

128. Reinders, A.; Ward, J.M. Functional characterization of the alpha-glucoside transporter Sut1p from Schizosaccharomyces pombe, the first fungal homologue of plant sucrose transporters. Mol. Microbiol. 2001, 39, 445-454. [CrossRef]

129. Gawaz, M.; Douglas, M.G.; Klingenberg, M. Structure-function studies of adenine nucleotide transport in mitochondria. II. Biochemical analysis of distinct AAC1 and AAC2 proteins in yeast. J. Biol. Chem. 1990, 265, 14202-14208. [CrossRef]

130. Kakhniashvili, D.; Mayor, J.A.; Gremse, D.A.; Xu, Y.; Kaplan, R.S. Identification of a novel gene encoding the yeast mitochondrial dicarboxylate transport protein via overexpression, purification, and characterization of its protein product. J. Biol. Chem. 1997, 272, 4516-4521. [CrossRef]

131. Tzagoloff, A.; Jang, J.; Glerum, D.M.; Wu, M. FLX1 codes for a carrier protein involved in maintaining a proper balance of flavin nucleotides in yeast mitochondria. J. Biol. Chem. 1996, 271, 7392-7397. [CrossRef]

132. Kim, H.; Melén, K.; Osterberg, M.; von Heijne, G. A global topology map of the Saccharomyces cerevisiae membrane proteome. Proc. Natl. Acad. Sci. USA 2006, 103, 11142-11147. [CrossRef]

133. Kolaj-Robin, O.; Russell, D.; Hayes, K.A.; Pembroke, J.T.; Soulimane, T. Cation Diffusion Facilitator family: Structure and function. FEBS Lett. 2015, 589, 1283-1295. [CrossRef] 
134. Swanson, R.; Locher, M.; Hochstrasser, M. A conserved ubiquitin ligase of the nuclear envelope/endoplasmic reticulum that functions in both ER-associated and Matalpha2 repressor degradation. Genes Dev. 2001, 15, 2660-2674. [CrossRef]

135. Dibrova, D.V.; Galperin, M.Y.; Mulkidjanian, A.Y. Characterization of the N-ATPase, a distinct, laterally transferred Na translocating form of the bacterial F-type membrane ATPase. Bioinformatics 2010, 26, 1473-1476. [CrossRef] [PubMed]

136. Sun, L.; Wang, H.; Wang, Z.; He, S.; Chen, S.; Liao, D.; Wang, L.; Yan, J.; Liu, W.; Lei, X.; et al. Mixed lineage kinase domain-like protein mediates necrosis signaling downstream of RIP3 kinase. Cell 2012, 148, 213-227. [CrossRef]

137. Radons, J. The human HSP70 family of chaperones: Where do we stand? Cell Stress Chaperones 2016, 21, 379-404. [CrossRef]

138. Bussink, H.-J.; Clark, A.; Oliver, R. The Cladosporium Fulvum Bap1 Gene: Evidence for a Novel Class of Yap-related Transcription Factors with Ankyrin Repeats in Phytopathogenic Fungi. Eur. J. Plant Pathol. 2001, 107, 655-659. [CrossRef]

139. Peleg, Y.; Aramayo, R.; Kang, S.; Hall, J.G.; Metzenberg, R.L. NUC-2, a component of the phosphate-regulated signal transduction pathway inNeurospora crassa, is an ankyrin repeat protein. Mol. Gen. Genet. 1996, 252, 709-716. [CrossRef]

140. Ichtchenko, K.; Khvotchev, M.; Kiyatkin, N.; Simpson, L.; Sugita, S.; Südhof, T.C. alpha-latrotoxin action probed with recombinant toxin: Receptors recruit alpha-latrotoxin but do not transduce an exocytotic signal. EMBO J. 1998, 17, 6188-6199. [CrossRef] [PubMed]

141. Mosavi, L.K.; Cammett, T.J.; Desrosiers, D.C.; Peng, Z.-Y. The ankyrin repeat as molecular architecture for protein recognition. Protein Sci. 2004, 13, 1435-1448. [CrossRef] [PubMed]

142. Rettig, J.; Heinemann, S.H.; Wunder, F.; Lorra, C.; Parcej, D.N.; Dolly, J.O.; Pongs, O. Inactivation properties of voltage-gated K channels altered by presence of $\beta$-subunit. Nature 1994, 369, 289-294. [CrossRef] [PubMed]

143. Postma, P.W.; Lengeler, J.W.; Jacobson, G.R. Phosphoenolpyruvate: Carbohydrate phosphotransferase systems of bacteria. Microbiol. Rev. 1993, 57, 543-594. [CrossRef] [PubMed]

144. Kuhn, M. Molecular Physiology of Membrane Guanylyl Cyclase Receptors. Physiol. Rev. 2016, 96, 751-804. [CrossRef] [PubMed]

145. Rincón, E.; Santos, T.; Ávila-Flores, A.; Albar, J.P.; Lalioti, V.; Lei, C.; Hong, W.; Mérida, I. Proteomics Identification of Sorting Nexin 27 as a Diacylglycerol Kinase ל-associated Protein. Mol. Cell. Proteom. 2007, 6, 1073-1087. [CrossRef] [PubMed]

146. Hage, H.; Rosso, M.-N. Evolution of Fungal Carbohydrate-Active Enzyme Portfolios and Adaptation to Plant Cell-Wall Polymers. J. Fungi 2021, 7, 185. [CrossRef]

147. Banasiak, J.; Jamruszka, T.; Murray, J.D.; Jasiński, M. A roadmap of plant membrane transporters in arbuscular mycorrhizal and legume-rhizobium symbioses. Plant Physiol. 2021, 187, 2071-2091. [CrossRef]

148. Ene, I.V.; Walker, L.A.; Schiavone, M.; Lee, K.K.; Martin-Yken, H.; Dague, E.; Gow, N.A.; Munro, C.A.; Brown, A.J. Cell Wall Remodeling Enzymes Modulate Fungal Cell Wall Elasticity and Osmotic Stress Resistance. mBio 2015, 6, e00986. [CrossRef]

149. Rosenblum, E.B.; Poorten, T.J.; Joneson, S.; Settles, M. Substrate-specific gene expression in Batrachochytrium dendrobatidis, the chytrid pathogen of amphibians. PLoS ONE 2012, 7, e49924. [CrossRef]

150. Monod, M. Secreted proteases from dermatophytes. Mycopathologia 2008, 166, 285-294. [CrossRef]

151. St Leger, R.J.; Cooper, R.M.; Charnley, A.K. Cuticle-degrading enzymes of entomopathogenic fungi: Regulation of production of chitinolytic enzymes. Microbiology 1986, 132, 1509-1517. [CrossRef]

152. Xiong, J.; Feng, J.; Yuan, D.; Zhou, J.; Miao, W. Tracing the structural evolution of eukaryotic ATP binding cassette transporter superfamily. Sci. Rep. 2015, 5, 16724. [CrossRef]

153. Vishwakarma, P.; Banerjee, A.; Pasrija, R.; Prasad, R.; Lynn, A.M. Phylogenetic and conservation analyses of MFS transporters. 3 Biotech 2018, 8, 462. [CrossRef] [PubMed]

154. Solomon, K.V.; Haitjema, C.H.; Henske, J.K.; Gilmore, S.P.; Borges-Rivera, D.; Lipzen, A.; Brewer, H.M.; Purvine, S.O.; Wright, A.T.; Theodorou, M.K.; et al. Early-branching gut fungi possess a large, comprehensive array of biomass-degrading enzymes. Science 2016, 351, 1192-1195. [CrossRef] [PubMed] 